\title{
Terrigenous Sediment Supply in the Polar to Temperate South Atlantic: Land-Ocean Links of Environmental Changes during the Late Quaternary
}

\author{
B. Diekmann ${ }^{1,2 *}$, D.K. Fütterer ${ }^{1}$, H. Grobe' ${ }^{1}$, C.D. Hillenbrand ${ }^{1}$, G. Kuhn' ${ }^{1}$, \\ K. Michels ${ }^{1}$, R. Petschick ${ }^{2}$ and M. Pirrung ${ }^{1}$
}

\author{
${ }^{I}$ Alfred-Wegener-Institut für Polar- und Meeresforschung, Columbusstraße, \\ 27515 Bremerhaven, Germany \\ ${ }^{2}$ Alfred-Wegener-Institut für Polar-und Meeresforschung, \\ Forschungsstelle Potsdam,Telegrafenberg A43, 14473 Potsdam, Germany \\ ${ }^{3}$ Geologisch-Palaeontologisches Institut, Universität Frankfurt,Senckenberganlage 32-34, \\ 60054 Frankfurt/Main, Germany \\ * corresponding author (e-mail): bdiekmann@awi-potsdam.de
}

\begin{abstract}
Terrigenous sediment parameters in modern sea-bottom samples and sediment cores of the South Atlantic are used to infer variations in detrital sources and modes of terrigenous sediment supply in response to environmental changes through the late Quaternary climate cycles. Massaccumulation rates of terrigenous sediment and fluxes of ice-rafted detritus are discussed in terms of temporal variations in detrital sediment input from land to sea. Grain-size parameters of terrigenous mud document the intensity of bottom-water circulation, whereas clay-mineral assemblages constrain the sources and marine transport routes of suspended fine-grained particulates, controlled by the modes of sediment input and patterns of ocean circulation. The results suggest low-frequency East Antarctic ice dynamics with dominant 100-kyr cycles and high rates of Antarctic Bottom Water formation and iceberg discharge during interglacial times. In contrast, the more subpolar ice masses of the Antarctic Peninsula also respond to short-term climate variability with maximum iceberg discharges during glacial terminations related to the rapid disintegration of advanced ice masses. In the northern Scotia Sea, increased sediment supply from southern South America points to extended ice masses in Patagonia during glacial times. In the southeastern South Atlantic, changes in regional ocean circulation are linked to global thermohaline ocean circulation and are in phase with northern-hemispheric processes of ice build-up and associated formation of North Atlantic Deep Water, which decreased during glacial times and permitted a wider extension of southern-source water masses in the study area.
\end{abstract}

\section{Introduction}

The South Atlantic plays an important role in the global climate system, as it represents the central junction box of ocean currents and water masses (Figs. 1, 2) that drive interhemispheric heat exchange (Keir 1988; Broecker and Denton 1989; Berger and Wefer 1996). The southern sector of the South Atlantic forms part of the circumpolar Southern Ocean, which provides the major conduit between the world oceans and maintains the thermal isolation of Antarctica. Marine sedimentary 'proxy' records in the South Atlantic document palaeoceanographic changes related to regional and 


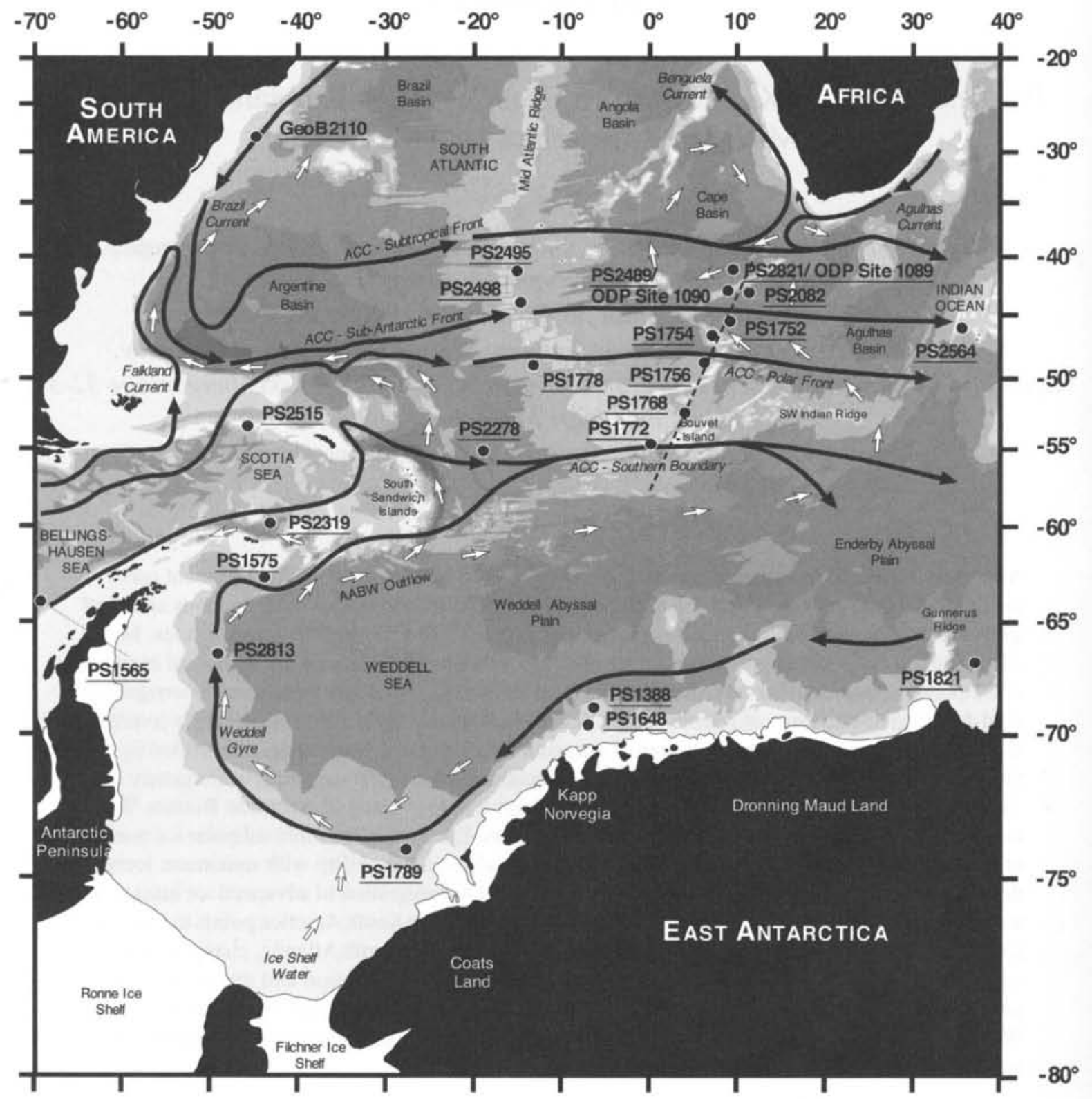

Fig. 1. Polar to temperate South Atlantic with locations of studied sediment cores. Black arrows show surface currents and the frontal system of the Antarctic Circumpolar Current (ACC) (Peterson and Stramma 1991; Orsi et al. 1995). The flow pattern of Antarctic Bottom Water (AABW), indicated by the white arrows, in many places appears independently from upper-level circulation (Georgi 1981; Tucholke and Embley 1984; Locarnini et al. 1993). Dashed line shows position of vertical water-mass profile depicted in Fig. 2. Sea floor below $2000 \mathrm{~m}$ is gradually shaded in steps of $1000 \mathrm{~m}$. 


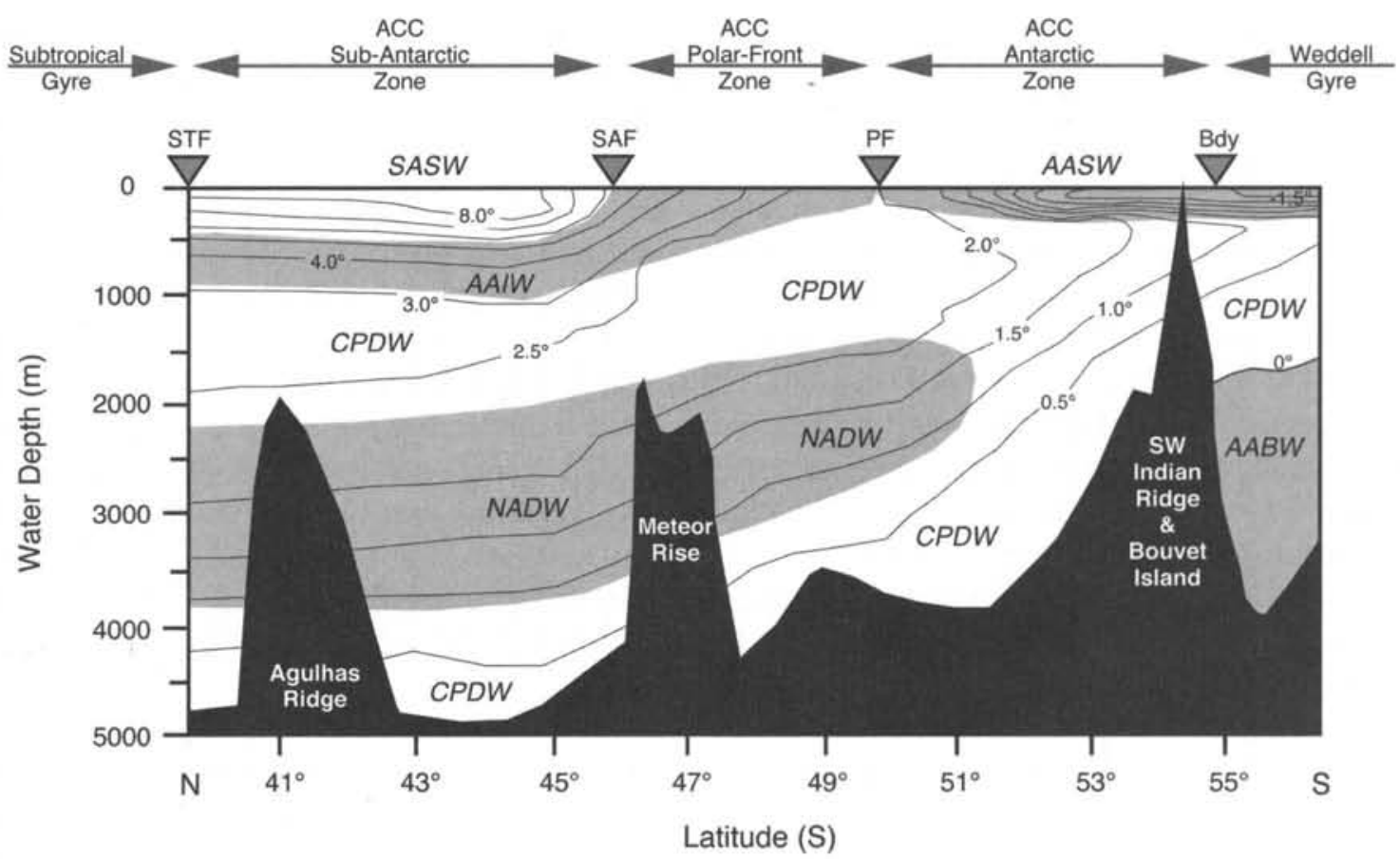

Fig. 2. Vertical distribution of water masses and potential temperatures on a north-south transect across the frontal system of the Antarctic Circumpolar Current (ACC) in the southeastern South Atlantic (see profile line in Fig. 1): (STF) Subtropical Front, (SAF) Subantarctic Front, (PF) Polar Front, (Bdy) boundary between ACC and Weddell Gyre, (SASW) Subantarctic Surface Water, (AASW) Antarctic Surface Water, (AAIW) Antarctic Intermediate Water, (NADW) North Atlantic Deep Water, (CPDW) Circumpolar Deep Water, (AABW) Antarctic Bottom Water. Modified from Gersonde et al. (1999).

global climate variability (Wefer et al. 1999). Moreover, they provide insights into Antarctic ice dynamics as a land-based factor of the southern-hemispheric climate system (Ehrmann 1994; Barrett 1996).

In this contribution, we will characterize terrigenous sediment supply to the temperate to polar South Atlantic and will highlight how terrigenous sediment parameters can be used to decipher the palaeoenvironment through the late Quaternary ice ages and interglacials. For a comprehensive overview of all aspects of terrigenous sedimentation, the reader is referred to the detailed compilations in respective textbooks (Chamley 1989; Lisitzin 1996; Anderson 1999). Since terrigenous sediments originate from terrestrial sources and are deposited in the ocean, they ideally record land-ocean links of climate processes. We will address fluxes of ter- rigenous mud and ice-rafted detritus as well as the granulometric and mineralogical properties of the detrital particles. The terrigenous sediment parameters will be reviewed in terms of Antarctic and Patagonian ice dynamics and regional ocean circulation.

\section{Material and Methods}

We refer to sea-bottom samples and sediment cores recovered in the South Atlantic and adjoining seas with research vessels 'Polarstern' (PS-samples) and 'Meteor' (GeoB-samples) during the last decades (Fig. 1, Table 1). Moreover, we present data from Site 1089 and Site 1090 of Leg 177 of the Ocean Drilling Program, which were drilled in the southeastern South Atlantic (Fig. 1, Table 1). The Site 1089 record was used to extend the PS2821 


\begin{tabular}{|c|c|c|c|c|c|c|}
\hline Sediment Core & Gear & Latitude & Longitude & Water Depth & Age Model & Reference \\
\hline GeoB2110-4 & Gravity Corer & $-28.650^{\circ}$ & $-45.521^{\circ}$ & $3003 \mathrm{~m}$ & Plankt. Foram. Biostrat. $/ \delta^{18} \mathrm{O}$ & Gingele et al. (1999) \\
\hline PS $1388-3$ & Gravity Corer & $-69.033^{\circ}$ & $-5.883^{\circ}$ & $2517 \mathrm{~m}$ & Plankt./Benth. Foram. $\delta^{18} \mathrm{O}$, Lithostrat. & Grobe and Mackensen (1992) \\
\hline PS1565-2 & Gravity Corer & $-63.924^{\circ}$ & $-69.544^{\circ}$ & $3427 \mathrm{~m}$ & Lithostratigraphy & Hillenbrand (1994) \\
\hline PS1575-1 & Gravity Corer & $-62.852^{\circ}$ & $-43.332^{\circ}$ & $3452 \mathrm{~m}$ & Litho-/Chemostratigraphy & Bonn et al. (1998) \\
\hline PS1648-1 & Gravity Corer & $-69.740^{\circ}$ & $-6.524^{\circ}$ & $2531 \mathrm{~m}$ & Lithostratigraphy & Grobe and Mackensen (1992) \\
\hline PS1752-1 & Gravity Corer & $-45.622^{\circ}$ & $9.597^{\circ}$ & $4519 \mathrm{~m}$ & Radiolarian Biostratigraphy & Brathauer and Abelmann (1999) \\
\hline PS1754-1 & Gravity Corer & $-46.770^{\circ}$ & $7.611^{\circ}$ & $2471 \mathrm{~m}$ & Planktonic Foraminifera $\delta^{18} \mathrm{O}$ & Niebler (1995), Frank et al. (1996) \\
\hline PS1756-4 & Gravity Corer & $-48.899^{\circ}$ & $6.714^{\circ}$ & $3787 \mathrm{~m}$ & Organic Carbon $\delta^{13} \mathrm{C}$, Radiol. Biostrat. & Frank et al. (1996), Abelmann (unpubl.) \\
\hline PS $1768-8$ & Gravity Corer & $-52.593^{\circ}$ & $4.475^{\circ}$ & $3270 \mathrm{~m}$ & Plankt. Foram. $\delta^{18} \mathrm{O} / \mathrm{AMS}^{14} \mathrm{C}$ & Niebler (1995), Frank et al. (1996) \\
\hline PS $1772-8$ & Gravity Corer & $-55.458^{\circ}$ & $1.164^{\circ}$ & $4135 \mathrm{~m}$ & Diatom Biostratigraphy & Frank et al. (1996) \\
\hline PS $1778-5$ & Gravity Corer & $-49.012^{\circ}$ & $-12.697^{\circ}$ & $3380 \mathrm{~m}$ & Radiolarian Biostratigraphy & Brathauer and Abelmann (1999) \\
\hline PS1789-1 & Gravity Corer & $-74.241^{\circ}$ & $-27.300^{\circ}$ & $2411 \mathrm{~m}$ & Planktonic Foraminifera AMS ${ }^{14} \mathrm{C}$ & Weber et al. (1994) \\
\hline PS $1821-6$ & Gravity Corer & $-67.064^{\circ}$ & $37.479^{\circ}$ & $3981 \mathrm{~m}$ & Lithostratigraphy & Bonn et al. (1998) \\
\hline PS2082-1 & Gravity Corer & $-43.220^{\circ}$ & $11.738^{\circ}$ & $4610 \mathrm{~m}$ & Benthic Foraminifera $\delta^{18} \mathrm{O}(80-250 \mathrm{ka})$ & Mackensen et al. (1994) \\
\hline PS2278-3 & Piston Corer & $-55.970^{\circ}$ & $-22.195^{\circ}$ & $4415 \mathrm{~m}$ & Diatom Biostratigraphy & Gersonde (unpublished) \\
\hline PS2319-1 & Gravity Corer & $-59.788^{\circ}$ & $-42.683^{\circ}$ & $4320 \mathrm{~m}$ & Radiolarian Biostratigraphy & Diekmann et al. (2000) \\
\hline PS2495-3 & Gravity Corer & $-41.288^{\circ}$ & $-14.500^{\circ}$ & $3135 \mathrm{~m}$ & Benthic Foraminifera $\delta^{18} \mathrm{O}$ & Mackensen et al. (2001) \\
\hline PS2498-1 & Gravity Corer & $-44.153^{\circ}$ & $-14.228^{\circ}$ & $3783 \mathrm{~m}$ & Benthic Foraminifera $\delta^{18} \mathrm{O}$ & Mackensen et al. (2001) \\
\hline PS $2515-3$ & Piston Corer & $-53.556^{\circ}$ & $-45.310^{\circ}$ & $3522 \mathrm{~m}$ & Radiol. Biostrat., Org. Carb. AMS ${ }^{14} \mathrm{C}$ & Diekmann et al. (2000) \\
\hline PS2564-3 & Piston Corer & $-46.141^{\circ}$ & $35.900^{\circ}$ & $3035 \mathrm{~m}$ & Benthic Foraminifera $\delta^{18} \mathrm{O}$ & Mackensen (unpublished) \\
\hline PS2813-1 & Piston Corer & $-66.730^{\circ}$ & $-50.000^{\circ}$ & $3499 \mathrm{~m}$ & Lithostratigraphy & Michels (unpublished) \\
\hline PS2821-1 & Piston Corer & $-40.943^{\circ}$ & $9.888^{\circ}$ & $4575 \mathrm{~m}$ & Radiolarian Biostratigraphy $(0-80 \mathrm{ka})$ & Cortese and Abelmann (2002) \\
\hline ODP Site 1089 & Advanced Piston Corer & $-40.936^{\circ}$ & $9.894^{\circ}$ & $4617 \mathrm{~m}$ & Benthic Foraminifera $\delta^{18} \mathrm{O}(80-250 \mathrm{ka})$ & Hodell et al. (2001) \\
\hline PS2489-2 & Piston Corer & $-42.873^{\circ}$ & $8.973^{\circ}$ & $3794 \mathrm{~m}$ & Benthic Foram. $\delta^{18} \mathrm{O}(0-408 \mathrm{ka})$ & Becquey and Gersonde (2002) \\
\hline ODP Site 1090 & Advanced Piston Corer & $-42.913^{\circ}$ & $8.899^{\circ}$ & $3700 \mathrm{~m}$ & Benthic Foram. $\delta^{18} \mathrm{O}(408-1800 \mathrm{ka})$ & Venz and Hodell (2002) \\
\hline
\end{tabular}

Table 1. Sediment-core locations with references to age models used. 
record from the same location, which only covers the last $80 \mathrm{kyr}$, back to $250 \mathrm{ka}$. The Site 1090 record covers the last $1800 \mathrm{kyr}$ and is spliced with the late Quaternary PS2489 record at $408 \mathrm{ka}$. Applied age models and assignments of marine isotope stages (MIS) are based on published foraminiferal $\delta^{18} \mathrm{O}$ records, biostratigraphy, or lithostratigraphy (Table 1), using the SPECMAP time scale (Imbrie et al. 1984). For the time-slice reconstruction of clay-mineral ratios in marine sediments, the values for the last glacial maximum (LGM) refer to average values found in samples of the recently defined LGM time interval between 23 and $19 \mathrm{ka}$ (calendar years BP), which corresponds to uncorrected ${ }^{14} \mathrm{C}$ ages between 20 and $16.5 \mathrm{ka}$ (Bard 1999). The GeoB sediment cores used for LGM reconstructions are specified on the Internet (www. pangaea.de/Institutes/GeoB/Cores/LGM.html, compiled by H.S. Niebler and S. Mulitza). Stratigraphic information for PS sediment cores is given by Gersonde et al. (in press). The Recent time slice is based on data from sea-bottom samples.

Mass-accumulation rates of terrigenous sediment (MART $\left[\mathrm{g} \mathrm{cm}^{-2} \mathrm{kyr}^{-1}\right]$ ) were calculated from sediment dry-bulk density multiplied by the relative proportion of the non-biogenic sediment fraction and linear sedimentation rates that depend on the applied age models. The non-biogenic fraction was determined by substracting the measured percentages of biogenic carbonate, biogenic opal and organic carbon (Kuhn and Diekmann 2002b). MART time-series were resampled to equal time increments of $2 \mathrm{kyr}$. The abundance of gravel clasts $>2 \mathrm{~mm}$, estimated from $\mathrm{x}$-radiographs, was used as a parameter of ice-rafted detritus (IRD) (Grobe 1987). Time-series of IRD flux are expressed as clast abundances per area and time unit $\left[\# \mathrm{~cm}^{-2}\right.$ $\mathrm{kyr}^{-1}$ ], by integrating counted IRD abundances at equal time increments of $1 \mathrm{kyr}$. The proportions of non-carbonate silt and clay (referred to as terrigenous mud) were determined by grain-size separation in settling tubes, after sieving the bulk samples through a $63-\mu \mathrm{m}$ mesh for separation of the sand fraction and dissolution of carbonate with 10-\% acetic acid (Brehme 1992; Kuhn and Diekmann 2002a, b). Silt grain-size analyses were con- ducted on sediment cores from the southern Cape Basin (Site 1089/PS2821) and the northwestern Weddell Sea (PS2515). The non-carbonate silt fraction was dispersed in sodium-polyphosphate solution and measured with a 'Micromeritics SediGraph 5000E' to determine the grain-size distribution in 1/10-Phi steps and hence the proportion of sortable silt (particle sizes 63-10 $\mu \mathrm{m}$ ) in the mud fraction (McCave et al. 1995). The bias of the terrigenous grain-size signal caused by biosiliceous particles in the non-carbonate mud fraction is negligible, because of relatively low opal concentrations that range between $3 \%$ and $7 \%$ in sediment core PS1575 (Bonn et al. 1998) and are $\leq 15 \%$ in the record of Site 1989/PS2821 (Kuhn and Diekmann 2002a, b). Moreover, no correlation exists between opal concentrations and grain-size variability for the latter record with the slightly elevated opal concentrations (Kuhn and Diekmann 2002b).

Clay-mineral data were obtained following standard procedures in marine geology (Biscaye 1965; Ehrmann et al. 1992; Petschick et al. 1996; Vogt 1997). Relative analytical precision for major clay minerals is $6-9 \%$ and $8-14 \%$ for minor clay minerals (Ehrmann et al. 1992). Although kaolinite and chlorite mostly represent minor components in the studied sediments $(<25 \%)$, the calculation of kaolinite/chlorite ratios is quite reliable, because the ratio is inferred from the double peak of $3.54 \AA$ (chlorite) and $3.58 \AA$ (kaolinite) in the $\mathrm{x}$-ray diffractograms (see details in Biscaye 1964; Petschick et al. 1996). Repeated sample preparations and measurements revealed a relative analytical error of $\leq 10 \%$ for kaolinite/chlorite ratios between 0.5 and 2.0 and around $20 \%$ for ratios $<0.5$ and $>2.0$ (Ehrmann et al. 1992; Vogt 1997). Ratios $<0.25$ and $>4.0$ have lower statistical confidence, which are not considered in this paper.

Temporal variation in grain-size spectra of terrigenous mud and the percentage of the four major clay-mineral groups smectite, illite, chlorite, and kaolinite are presented at equal time increments of $2 \mathrm{kyr}$. The conversion of original data into data at equal time steps was facilitated by the 'AnalySeries' software through linear integration between original data points (Paillard et al. 1996). 


\section{Spatial and Temporal Patterns of Terrigenous Sediment Supply}

Terrigenous sediments in the study area are dominated by silt- and clay-sized detritus with small proportions of sand and gravel delivered by icebergs and/or sea ice. High concentrations of icerafted detritus (IRD) only appear on the shelves off Antarctica, while they range below $15 \%$ beyond the shelves (Diekmann and Kuhn 1999). In this section, we will refer to mass-accumulation of total terrigenous sediment (MART) and discuss IRD fluxes during the last $250 \mathrm{kyr}$.

\section{Mass-Accumulation Rates of Terrigenous Sediment (MART)}

The calculation of MARTs quantifies the deposition of terrigenous sediment, mainly of mud, at a given location and thus gives an impression of the detrital input and the terrigenous sediment fluxes in the ocean. MARTs at the selected sediment-core locations show high spatial and temporal variability in the range between 0.1 and $10 \mathrm{~g} \mathrm{~cm}^{-2} \mathrm{kyr}^{-1}$, with exceptionally high values of up to $150 \mathrm{~g} \mathrm{~cm}$. ${ }^{2} \mathrm{kyr}^{-1}$ in the southeastern Weddell Sea (PS1789) (Fig. 3). Compared to the tropical South Atlantic, where terrigenous input is dominated by almost pure aeolian sediment supply with MARTs that rarely exceed values $>1.2 \mathrm{~g} \mathrm{~cm}^{-2} \mathrm{kyr}^{-1}$ through time (Ruddiman 1997), the often high MARTs in the temperate to polar South Atlantic document a variety of processes that are responsible for terrigenous sediment dispersal.

On average, elevated MART values $(>2.5 \mathrm{~g}$ $\mathrm{cm}^{-2} \mathrm{kyr}^{-1}$ ) appear off the continental margins because of the proximity to detrital sources. High values are also evident in the distal regions of the Weddell Sea and the Scotia Sea, where the dispersal of fine-grained glacigenic detritus and reworking of marine sediments by the bottom currents of the Weddell Gyre and the Antarctic Circumpolar Current is promoted. The sea floor in the Scotia Sea exhibits widespread scour features, which are often associated with a lack of Quaternary sediment cover (Pudsey and Howe 1998). Sediment accumulation is focused and restricted to current-sheltered depressions, like at core locations PS2319 and PS2515. High accumulation rates also characterize drift deposits in the southern Cape Basin (PS2821/Site 1089), which are influenced by bottom contour currents (Kuhn and Diekmann 2002a). MARTs in the remote eastern ACC region are variable and mostly low $\left(<1.0 \mathrm{~g} \mathrm{~cm}^{-2} \mathrm{kyr}-1\right)$, with slightly increased values at core location PS2498 $\left(>2.0 \mathrm{~g} \mathrm{~cm}^{-2} \mathrm{kyr}^{-1}\right)$ on the Mid-Atlantic Ridge. Spatial variability in average MARTs points to lateral particle advection within the water masses of the ACC, leading to marked winnowing and focusing effects. The importance of lateral sediment transport is also apparent from the calculation of thorium-normalized flux rates $\left({ }^{230} \mathrm{Th}\right.$ exess data) of biogenic sediment constituents (Frank et al. 1996).

Glacial-interglacial MART fluctuations show an inconsistent pattern. Along Antarctica, MARTs are increased during glacial stages at core locations on drifts and levee deposits in channel systems that incise the continental margins of the Weddell Sea and the Bellingshausen Sea. Two examples are location PS1565 on the continental rise off the Antarctic Peninsula (Hillenbrand 2000) and location PS1789 on the continental slope in the southeastern Weddell Sea. MARTs at the latter location were approximately 15 times higher during the last glacial stage than during the Holocene (Weber et al. 1994). Higher sediment fluxes during cold stages with low sea levels are caused by the "bulldozing effect" of shelf-grounded ice sheets that triggers turbidity currents to the deep-sea (Grobe and Mackensen 1992). The formation of levee structures documents the interaction of contour currents and turbidity currents (Weber et al. 1994; Rebesco et al. 1996; Diekmann and Kuhn 1997; Hillenbrand 2000; Michels et al. 2002). It is assumed that the suspensions of the turbidity currents are deflected by coriolis forcing during their downslope movement through the channels, and that parts of their overspilling sediment loads are entrained in contour currents.

In the Scotia Sea, high MARTs are also related to glacial stages (PS2319 and PS2515). Higher sediment fluxes in the ACC can be explained by strong glacigenic sediment input from the Antarctic Peninsula and from Patagonia in response to extended ice sheets that reach the open ocean and the shelf edges (Diekmann et al. 2000; Walter et 

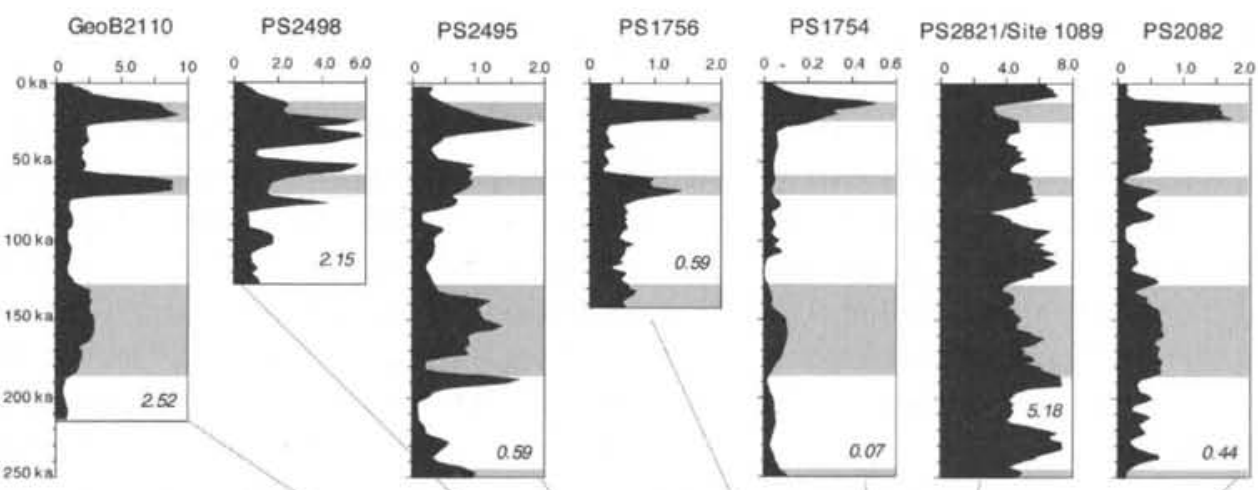

PS2564
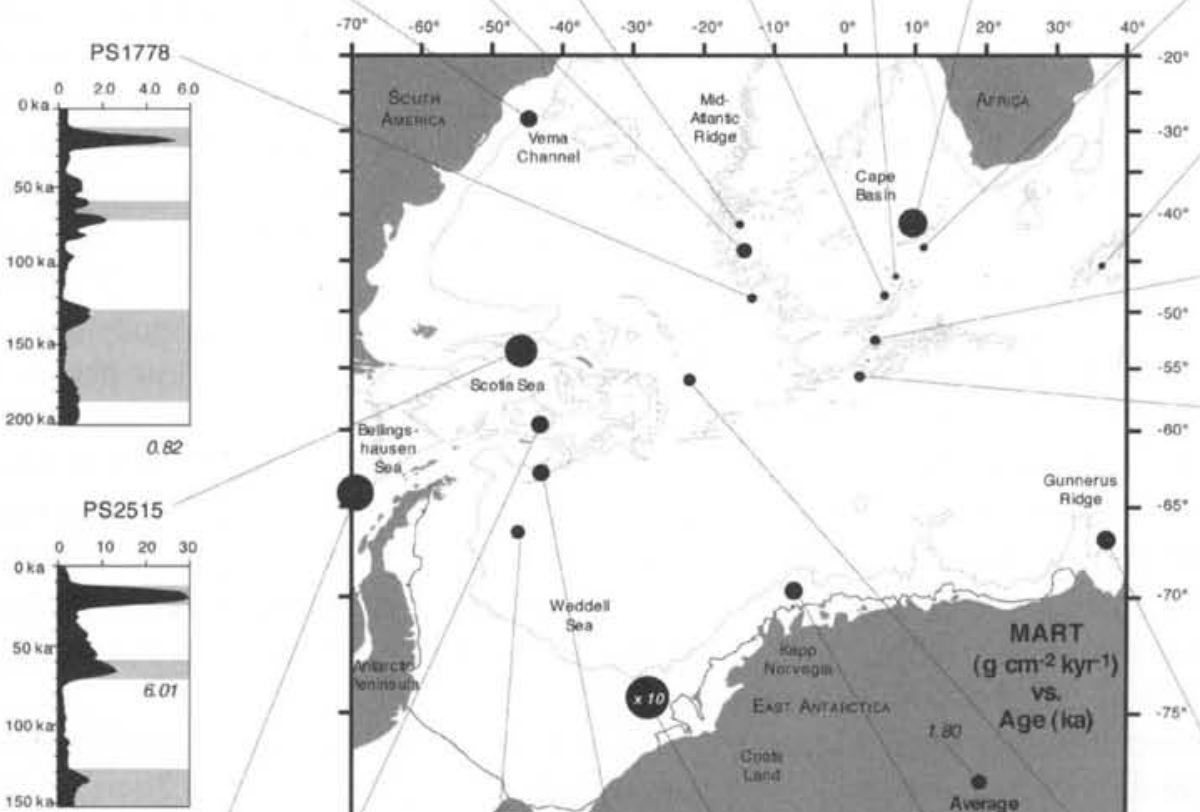

PS1768
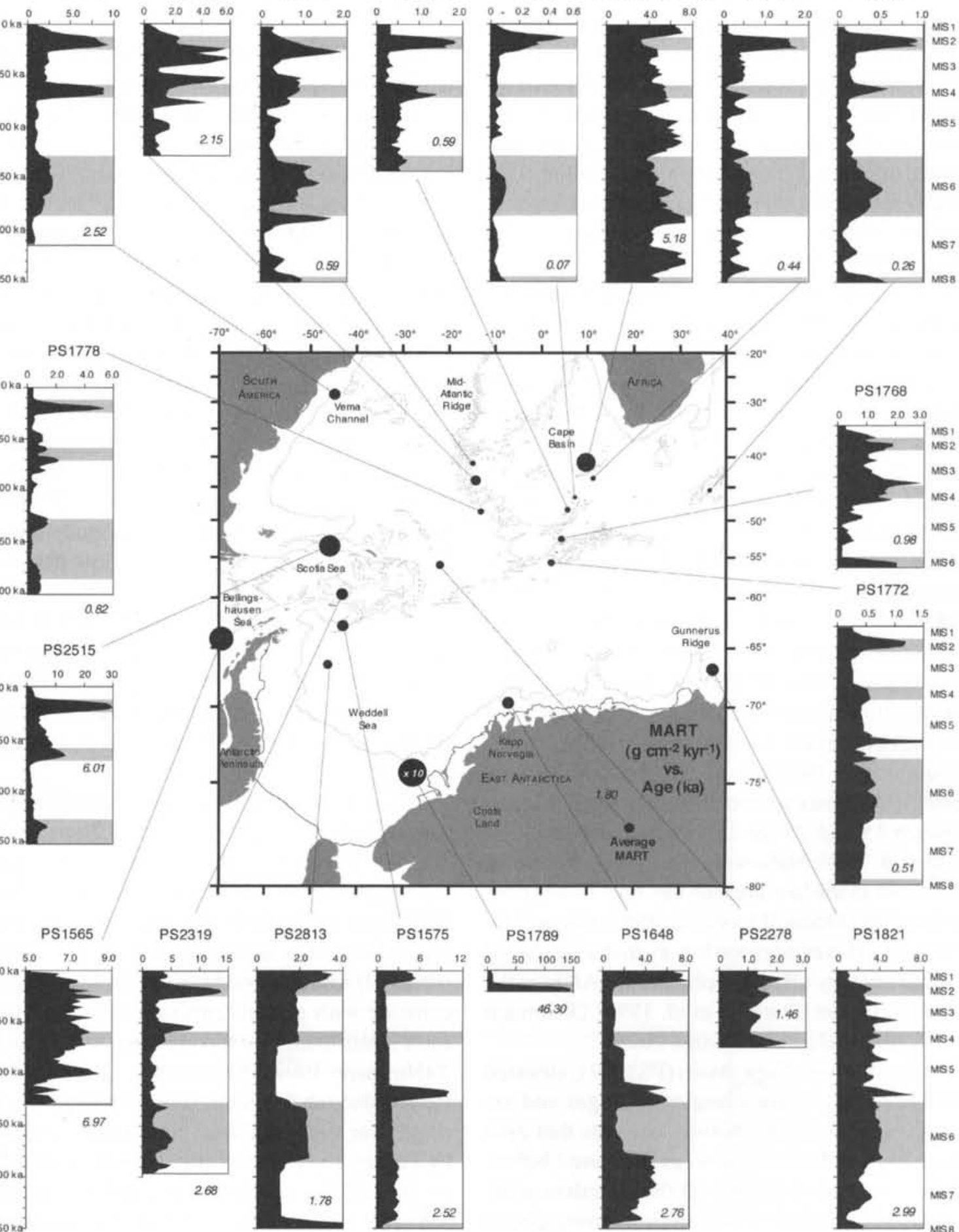

PS1821

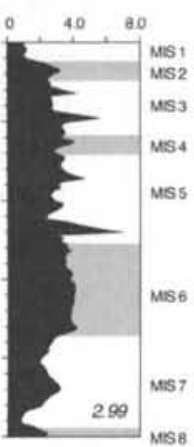

Fig. 3. Temporal and spatial variability of mass-accumulation rates (MART) of terrigenous sediment (MART) recorded in sediment cores of the study area. Diagrams display MARTs in $\mathrm{g} \mathrm{cm}^{-2} \mathrm{kyr}^{-1}$ versus age in ka (last 250 kyr) with indication of average MART value (italic number) and marine isotope stages (glacial stages in grey). Black circles on the map are proportional to average MARTs in the respective sediment cores. Bathymetry is indicated by the $3000-\mathrm{m}$ contour line. 
al. 2000). Furthermore, a stronger wind-forcing of the ACC during glacial times enhances transport capacity of the ACC (Pudsey and Howe 1998; Howe and Pudsey 1999). Elevated MARTs during glacial intervals that document increased detrital fluxes in the water masses of the ACC are also evident at many distal core locations farther eastward from the Scotia Sea. This area is characterized by dense nepheloid suspension layers (Biscaye and Eittreim 1977).

It has been suggested that increased detrital fluxes might reflect an increased long-distance supply of air-borne dust from Patagonia due to increased continental aridity and/or enhanced wind strengths of the southern-hemispheric westerlies during glacial times (Martin 1990; Kumar et al. $1995)$. However, this suggestion is not well supported by provenance analyses taking into account the mineralogical and geochemical composition (major and trace elements, neodymium and strontium isotopes) of marine muds (Bareille et al. 1994; Diekmann et al. 2000; Walter et al. 2000). Clues for stronger atmospheric dust fluxes during glacial times actually arise from increased dust concentrations of Patagonian origin in the ice cores from the East Antarctic ice sheet (Petit et al. 1990; Grousset et al. 1992). The Vostok dust record for example suggests greater dust fluxes by a factor between 15 and 25 for the last glacial maximum (Petit et al. 1990; Mahowald et al. 1999). However, in relation to the low present-day dust fluxes over the Southern Ocean (Duce et al. 1991; Husar et al. 1997), dust fluxes were too low even during glacial times to strongly affect the observed MARTs in the Southern Ocean (Bareille et al. 1994; Diekmann et al. 1999; Maher and Dennis 2001).

In the southern Cape Basin (PS2821), elevated MARTs occur during interglacial stages and are consistent with strong bottom currents that give rise to high sediment fluxes, as discussed below. At the continental margin off the Brazilian coast (GeoB 2110), higher MARTs appear during glacial periods and likely reflect a higher sediment input across the shelf edge, caused by low sea levels (Massé et al. 1996; Diekmann et al. 1999).

\section{Ice-Rafted Detritus (IRD)}

Although IRD only forms a small proportion of the terrigenous sediment fraction, its spatial and temporal distribution provides important insights into icesheet dynamics and the extent of cold surface water masses that control the distribution and survival of both icebergs and sea ice. The spatial IRD distribution does not show a simple proximal to distal marine gradient as is more or less displayed by the MARTs (Fig. 4). High IRD fluxes (4.23 $\mathrm{n} \mathrm{cm}$ ${ }^{2} \mathrm{kyr}^{-1}$ ) appear in the southeastern Weddell Sea off Coats Land (PS1789), where prominent ice streams drain the East Antarctic ice sheet, while average IRD fluxes off Dronning Maud Land (PS1648, PS1388, PS1821) are moderate to low $\left(0.04-1.16 \mathrm{n} \mathrm{cm}^{-2} \mathrm{kyr}\right.$ 1). Moderate IRD fluxes $\left(0.48 \mathrm{n} \mathrm{cm}^{-2} \mathrm{kyr}^{-1}\right)$ also appear in the Bellingshausen Sea off the Antarctic Peninsula (PS1565). In the pelagic study area, the Polar Front delineates an area with low IRD fluxes $\left(\leq 0.15 \mathrm{n} \mathrm{cm}^{-2} \mathrm{kyr}^{-1}\right)$ and warm surface waters to the north from the remaining area with moderate to high IRD fluxes $\left(>0.2 \mathrm{n} \mathrm{cm}^{-2} \mathrm{kyr}^{-1}\right)$, which is occupied by cold water masses. Unusually elevated average IRD fluxes $\left(>2.0 \mathrm{n} \mathrm{cm}^{-2} \mathrm{kyr}^{-1}\right)$ appear east of the South Sandwich Islands (PS2278) and near Bouvet Island (PS1768).

Temporal fluctuations reveal systematic regional trends. In the Weddell Sea, apart from location PS1789, higher IRD fluxes are related to interglacial stages (Grobe and Mackensen 1992). Marked IRD fluxes in the Bellingshausen Sea off the Antarctic Peninsula (PS1565) and in the southern (PS2319) and the northern Scotia Sea (PS2515) coincide with glacial terminations and moreover show small short-term spikes during MIS 3 and MIS 2 (Hofmann 1999; Diekmann et al. 2000). In the Bellingshausen Sea, short-term fluctuations in IRD supply for the last glacial period were also noted by Pudsey and Cammerlenghi (1998) and Cofaigh et al. (2001). At the two southern locations (PS1565, PS2319), short-term IRD fluctuations are moreover evident for MIS 5. In the southeastern Atlantic maximum IRD fluxes appear during glacial stages. High-resolution IRD records from ODP 

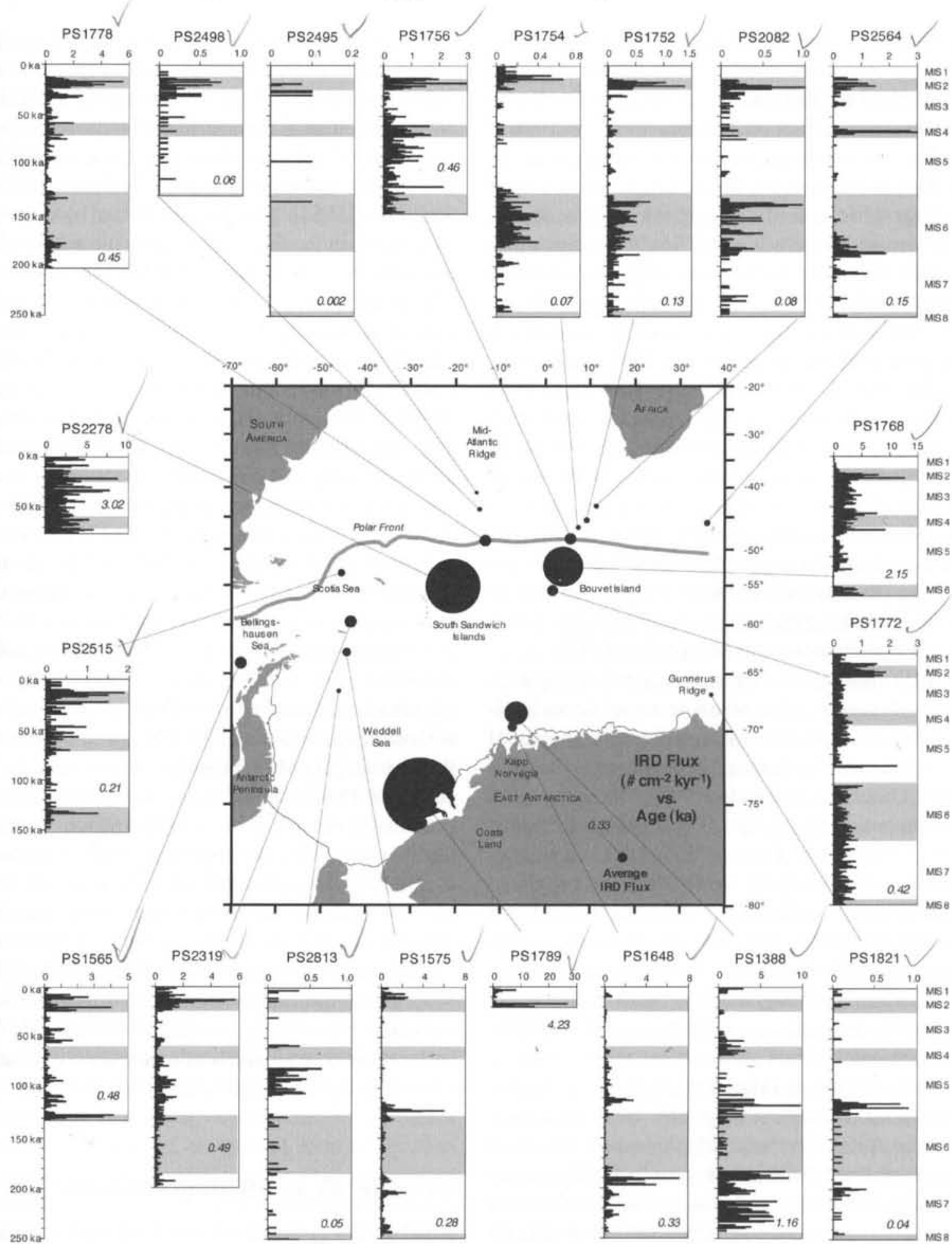

Fig. 4. Temporal and spatial variability of flux rates of ice-rafted detritus (IRD) recorded in sediment cores of the study area. Diagrams display IRD fluxes in $\# \mathrm{~cm}^{-2} \mathrm{kyr}^{-1}$ versus age in ka (last $250 \mathrm{kyr}$ ) with indication of average IRD value (italic number) and marine isotope stages (glacial stages in grey). Black circles on the map are proportional to average IRD values in the respective sediment cores. 
sites in the same area were interpreted to mark shortterm IRD events during MIS 3, which likely correspond to interstadials in the northern hemisphere (Kanfoush et al. 2000).

For the interpretation of IRD fluxes, it is important to consider the IRD sources inferred from petrographic and mineralogical studies. In the southern and eastern Weddell Sea, the composition of IRD generally points to nearby source rocks, with abundant clasts derived from East Antarctic crystalline basement rocks, carried by icebergs in the course of the Weddell Gyre (Oskierski 1988; Anderson et al. 1989; Diekmann and Kuhn 1999). In the northwestern Weddell Sea, a minor IRD contribution from the eastern Antarctic Peninsula slightly dilutes the East Antarctic signal (Edwards and Goodell 1969; Diekmann and Kuhn 1999). In the Weddell Sea, the generally higher IRD fluxes during interglacial stages thus document increased calving rates of icebergs from floating ice masses of the East Antarctic ice sheet during high stands of sea level (Grobe and Mackensen 1992).

IRD clasts in the Bellingshausen Sea originate from Mesozoic and Cainozoic intrusive and volcanic rocks as well as meta-sedimentary rocks of the Antarctic Peninsula (Edwards and Goodell 1969; Diekmann and Kuhn 1999). Magmatic rocks also make up a high proportion of IRD in the Scotia Sea (Conolly and Ewing 1965; Diekmann et al. 2000). In the northern Scotia Sea, the supply of IRD from the Pacific sector of the Southern Ocean is supplemented by IRD from the southern Andean magmatic belt during glacial times and terminations, when the Patagonian ice fields coalesce and expand to the open ocean (Diekmann et al. 2000). In contrast to East Antarctica, where intense iceberg calving is related to interglacial stages, maximum iceberg calving rates from Patagonia and the Antarctic Peninsula document the rapid disintegration of marine ice masses during climate amelioration associated with glacial terminations and less pronounced during short-term climate perturbations (Hofmann 1999; Diekmann et al. 2000). Patagonian land records are consistent with these findings and moreover suggest interhemispheric teleconnections with northernhemispheric climate dynamics (Lowell et al. 1995; Heusser et al. 2000; McCulloch et al. 2000).
The area between the southwest Atlantic and the Indian sector of the Southern Ocean represents an IRD province with high abundances of volcaniclastic glass shards, pumice and volcanic rock fragments mostly derived from the South Sandwich Islands and other islands (Conolly and Ewing 1965; Smith et al. 1983). This fact is reflected by elevated IRD fluxes in the vicinity of such source areas, for example PS2278 northeast of the South Sandwich Islands and PS1768 near Bouvet Island. The association of high IRD fluxes with late Quaternary glacial stages and reduced IRD fluxes north of the Polar Front underlines the major control of seasurface temperatures on the dispersal of IRD (Smith et al. 1983; Labeyrie et al. 1986; Allen and Warnke 1991; Becquey and Gersonde 2002; Pirrung et al. 2002). The interpretation of IRD fluxes in terms of Antarctic ice-sheet dynamics in this IRD province is hence complicated for several reasons: (1) the temperature effect on the survival of icebergs, (2) IRD sources from offshore Antarctica, (3) the possible sea-ice transport of volcanic ashes (Cooke and Hays 1982; Smith et al. 1983), (4) the impact of episodic volcanic eruptions that are not coupled with climate variability. An attempt to overcome these unpredictable volcanic influences is to calculate the fluxes of ice-rafted quartz, which presumably is solely derived from Antarctic sources (Smith et al. 1983; Labeyrie et al. 1986; Kanfoush et al. 2000). This approach has to be regarded with caution, because quartz as a major rock-forming mineral is supplied from a variety of Antarctic sources and because the temporal variability of IRD supply from East and West Antarctic sources differs markedly. Furthermore, the glacial-interglacial IRD patterns observed in the south-east Atlantic clearly contradict those along the Antarctic continent.

\section{Sortable Silt and Bottom Currents}

Apart from the modes of sediment input (glacial, aeolian and fluvial supply), the grain-size distribution of terrigenous muds is determined by bottomcurrent strengths and its impact on winnowing and focusing effects and selective grain-size transport within nepheloid layers. Granulometric analyses of the terrigenous mud fraction are often used to de- 
duce the influence of current-induced particle transport (Ledbetter 1986; McCave et al. 1995; Höppner and Henrich 1999), although the method is not indisputable (e.g. Anderson and Kurtz 1985). The basic idea is that the terrigenous mud fraction is mostly delivered by lateral sediment supply and susceptible to current sorting by deep-sea currents. In contrast, the grain-size distribution of biogenic particles, in addition to current sorting, is inherited from the modes of biological productivity and mainly originates from the vertical settling of skeletal planktonic remains through the water column, and is also affected and modified by dissolution processes in the water and the sediment column, especially in the South Atlantic (Bickert and Wefer 1996; Diekmann and Kuhn 1997; Dittert et al. 1999). One well established grain-size parameter is the percentage of so-called "sortable silt" (grain size $63-10 \mu \mathrm{m}$ in diameter) in terrigenous mud. It represents the mud fraction that is transported as single grains, whereas finer grained material is affected and modified by cohesive aggregation of particles (Mc Cave et al. 1995).

In the study area, the reconstruction of palaeo bottom-current speeds on the basis of terrigenous silt grain size provides information about the relative dynamics of Circumpolar Deep Water (CPDW), the deepest water mass of the ACC, and Antarctic Bottom Water (AABW). AABW represents the deepest water mass in the study area, which is confined to the abyssal basins and trenches and directed by both thermohaline circulation and topography (Figs. 1, 2). The reconstruction of $\mathrm{AABW}$ dynamics is of palaeoclimatic interest, since its production is linked to Antarctic ice-sheet behaviour and at present depends to a large part on the presence of floating ice shelves. Today, it is formed as a mixture of various polar water masses around the Antarctic margins. A large proportion originates in the Weddell Sea by processes related to sea-ice formation and associated brine release as well as supercooling mechanisms beneath the Filchner-Ronne Ice Shelves (Foldvik and Gammelsrød 1988; Fahrbach and Beckmann 2001). The northward spread of dense AABW contributes to the ventilation of the abyssal world ocean.

Grain-size records of CPDW dynamics from the Scotia Sea basically indicate a stronger current activity during glacial stages, because of a stronger wind-forcing of the ACC by the southern-hemispheric westerlies (Howe and Pudsey 1999; Hofmann 1999). Previous studies on the timing of glacial-interglacial variability in AABW flow, however, have revealed inconsistencies. In the channel systems off the Filchner Trough, which partly drain cold Ice Shelf Water, the hemipelagic muds of levee deposits tend to be coarser grained in glacial intervals (Weber et al. 1994). However, these grain-size records are likely affected by granulometric signals produced by turbidity currents, as revealed by mineralogical provenance analyses of the muds (Diek-mann and Kuhn 1997). In the northwestern Weddell Sea, coarse-grained muds are clearly associated with interglacial intervals (Fütterer et al. 1988; Pudsey 1992; Gilbert et al. 1998). A grain-size record from the southern South Orkney continental slope (PS1575) displays maximum values in substages of MIS 7 and MIS 5 and in the Holocene (Brehme 1992) (Fig. 5). Along the western branch of the AABW outflow path, a maximum in the early Holocene contrasts with minimum values in MIS 2 and the late Holocene in a sediment core from the South Sandwich Trench (Diekmann and Kuhn 1997). Farther north, the Vema Channel between the Argentine Basin and the Brazil Basin represents another focus of AABW outflow, where relatively increased $\mathrm{AABW}$ current strengths coincide with interglacial-glacial transitions (Ledbetter 1986; Massé et al. 1994).

The reconstruction of $\mathrm{AABW}$ dynamics generally suffers from the poor age constraints of the sediment records under discussion, which all were recovered from water depths below the carbonate lysocline and thus do not permit any age assignments by foraminiferal oxygen-isotope stratigraphy. In the recent past, a well-dated and high-resolution grain-size record was obtained from sediment core PS2821/Site1089, which was recovered on a drift deposit in the southern Cape Basin and which already was addressed for the discussion of MARTs (Kuhn and Diekmann 2002a) (Figs. 1, 3, 5). The carbonate-bearing drift sediments were deposited at high sedimentation rates $\left(15-20 \mathrm{~cm} \mathrm{kyr}^{-1}\right)$ and MARTs (3-7 $\mathrm{g} \mathrm{cm}^{-2} \mathrm{kyr}^{-1}$ ) under the influence of clockwise contour currents that are prevalent in the 


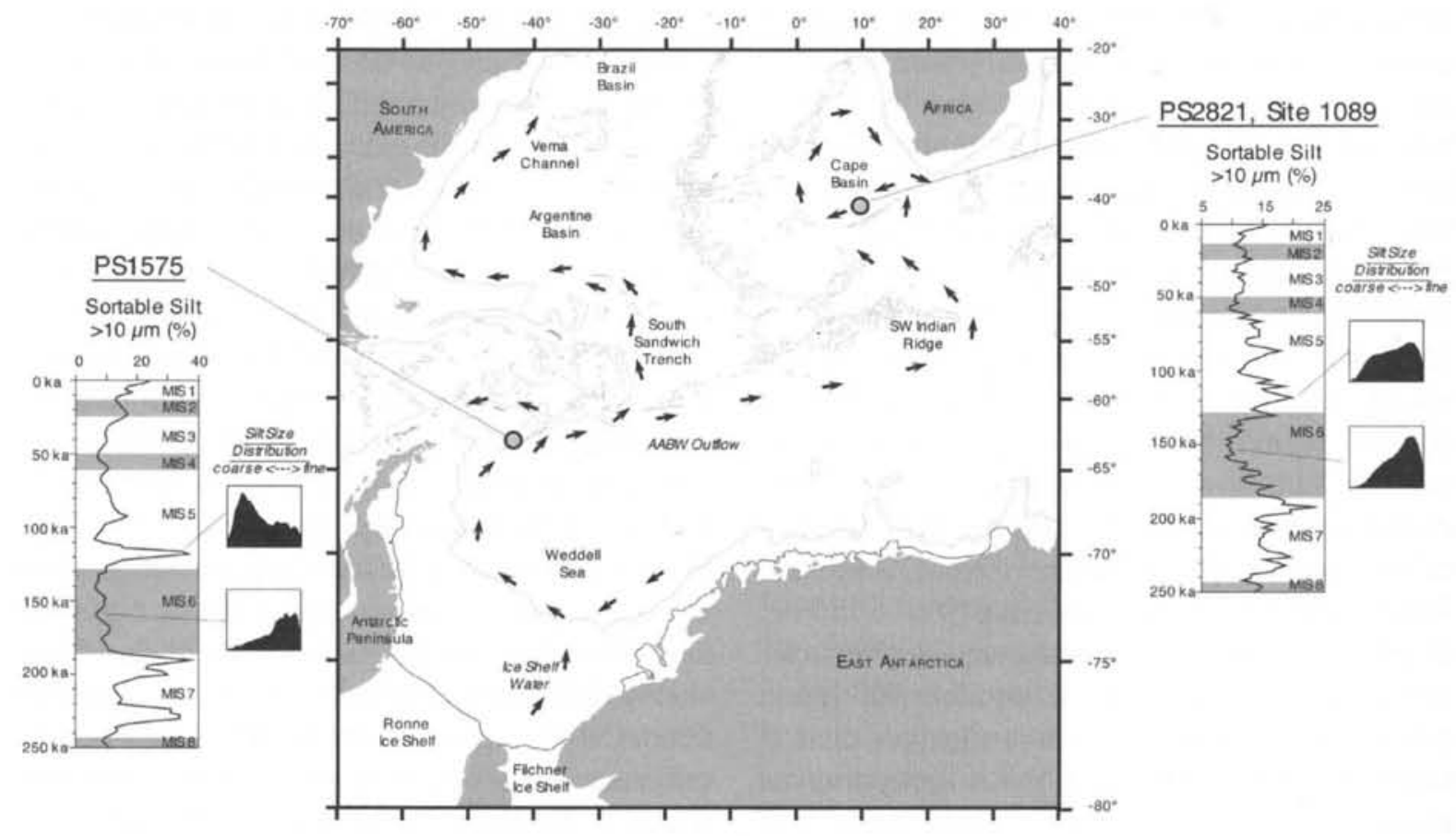

Fig. 5. Temporal variability (last $250 \mathrm{kyr}$ ) of percentages of sortable silt in two sediment cores from the northwestern Weddell Sea (PS1575) and the southern Cape Basin (PS2821/Site 1089). Small insets show silt-grain size distribution curves of characteristic glacial and interglacial sediment-core intervals, respectively. Diagrams include indication of marine isotope stages (glacial stages in grey). Black arrows delineate the flow paths of Antarctic Bottom Water. Bathymetry is indicated by the $3000-\mathrm{m}$ contour line.

abyssal Cape Basin. These bottom currents oppose the general eastward ACC jets and originate in the northward outflow of the AABW through gaps of the SW Indian Ridge (Bornhold and Sum-merhayes 1977; Tucholke and Embley 1984) (Fig. 1).

Downcore variations in the percentage of sortable terrigenous silt at location PS2821/Site 1089 demonstrate fluctuations with affinities to glacialinterglacial cycles (Fig. 5). Minimum values are related to glacial intervals and point to a relative decrease in abyssal current strengths. Abundant pyrite streaks in the glacial sediment intervals indeed support the interpretation of reduced bottomwater ventilation (Kuhn and Diekmann 2002a). Values of maximum sortable silt correspond to interglacial optimum values, comprising the substages MIS 7.5 and 7.1, MIS 5.5, 5.3 and 5.1 and MIS 1 . These maximum values actually exhibit a good correlation with maximum values recorded in sediment core PS1575 recovered from the northwestern Weddell Sea (Fig. 5), which was dated by lithostratigraphic and chemostratigraphic methods (Bonn et al. 1998). Time-series analyses of the silt grain-size parameter at location PS2821/Site 1089 reveal spectral power in the $100-\mathrm{kyr}^{-1}$ frequency domain of Milankovitch cycles, but lack significant spectral power in the $40-\mathrm{kyr}^{-1}$ and $23-\mathrm{kyr}^{-1}$ frequency bands (Kuhn and Diekmann 2002a). This finding is consistent with maximum $\mathrm{AABW}$ formation during high stands of sea level that permit the supercooling mechanism of waters beneath floating ice shelves, particularly in the southern Weddell Sea. Since AABW production is strongly coupled with ice-sheet behavior, another conclusion is that the polar ice masses of Antarctica respond less sensitively to short-term climate 
variability and sea-level fluctuations than the more subpolar ice masses of Patagonia.

\section{Clay Minerals as Tracers of Sediment Provenance and Dispersal}

A crucial aspect of terrigenous sediment supply in the study area is the identification of terrigenous sediment sources. Because of the dominance of fine-grained muds, clay mineralogy is an appropriate tool to constrain the origin of terrigenous sediments. The composition of terrestrial clay minerals reflects the development of prevailing weathering regimes in the continental source areas, which depend on the climate zonation that determine the intensity of pedogenesis and chemical and physical weathering (Chamley 1989). In the South Atlantic, late Quaternary clay-mineral assemblages constrain the sources and marine transport paths of clay-sized material in response to climate variability and its impacts on the modes of sediment input and ocean circulation.

\section{Modern Clay-Mineral Provinces}

The general distribution pattern of terrigenous claymineral assemblages in the whole South Atlantic highlights the sedimentary processes that control their distribution. A detailed clay-mineralogical survey of modern sea-bottom sediments in the South Atlantic was first undertaken by Biscaye (1965) and more recently by Petschick et al. (1996). The latter authors particularly provided an improved knowledge of clay-mineral distributions in the higher latitudes of the South Atlantic. The major clay-mineral provinces are well displayed by claymineral assemblages, as defined by the proportions of the three clay-mineral groups illite, kaolinite, and chlorite in a ternary concentration diagram (Fig. 6). The interpretation of smectite minerals is enigmatic, because they can be of both terrigenous and authigenic marine origin (Chamley 1997). The configuration of clay-mineral provinces reveal kaolinite- and chlorite-bearing assemblages to represent contrasting end members of the low and high latitudes, respectively (Fig. 6). Provinces dominated by the kaolinite end member or by mixed kaolinite-illite assemblages appear north of the ACC region, whereas mixed illite-chlorite assemblages are restricted to the south.

In the equatorial regions, kaolinite-dominated assemblages appear off tropical Africa and off the Brasilian Coast, increasingly diluted by illite toward the pelagic South Atlantic. In Africa, the large tropical Congo and Niger rivers as well as trade winds from the Sahel Zone supply detrital particles rich in kaolinite from fossil and modern tropical soils (Aston et al. 1973; Pastouret et al. 1978; Van der Gaast and Jansen 1984; Gingele et al. 1998). Off Brazil, fluvial suspensions, originating from deeply weathered basement rocks (laterites) of the Santos/ Sao Paulo Plateaus, provide the bulk of kaolinite in marine sediments (De Melo et al. 1975; Gingele et al. 1999). The western coastal area of southern Africa is characterized by an illite-dominated claymineral province that passes to illite-kaolinite assemblages farther offshore. Deserts and semi-arid regions of southern Africa are major contributors of illite, supplied by the southeastern trade winds and to a lesser degree by fluvial input (Bremner and Willis 1993; Gingele 1996). The transition to illitekaolinite assemblages farther offshore indicates an increasing influence of kaolinite-bearing detritus from northern sources, supplied by deep-water advection (Petschick et al. 1996). Kaolinite is also delivered by the Agulhas Current that brings detrital material from the subtropical regions of eastern Africa to the South Atlantic (Kolla et al. 1976).

Marine sediments underlying the ACC exhibit highest chlorite concentrations of the entire South Atlantic. Chlorite originates from the Andean mobile belts of South America and the Antarctic Peninsula distributed by the ACC, with possibly minor aeolian contributions (Petschick et al. 1996; Diekmann et al. 2000; Hillenbrand and Ehrmann 2001; Hillenbrand et al. 2003). The influence of southern-source water masses on particle advec-tion is well displayed by latitudinal gradients of kaolinite/ chlorite ratios in sea-bottom sediments, with decreasing kaolinite/chlorite ratios from north to south. In the southwestern Atlantic, northward particle transport by deep southern-source water masses is also indicated by displaced Anatarctic diatoms (Jones and Johnson 1984) and the pattern of strontium isotope signatures in sea-bottom sediments (Biscaye and Dasch 1971). Another illite 

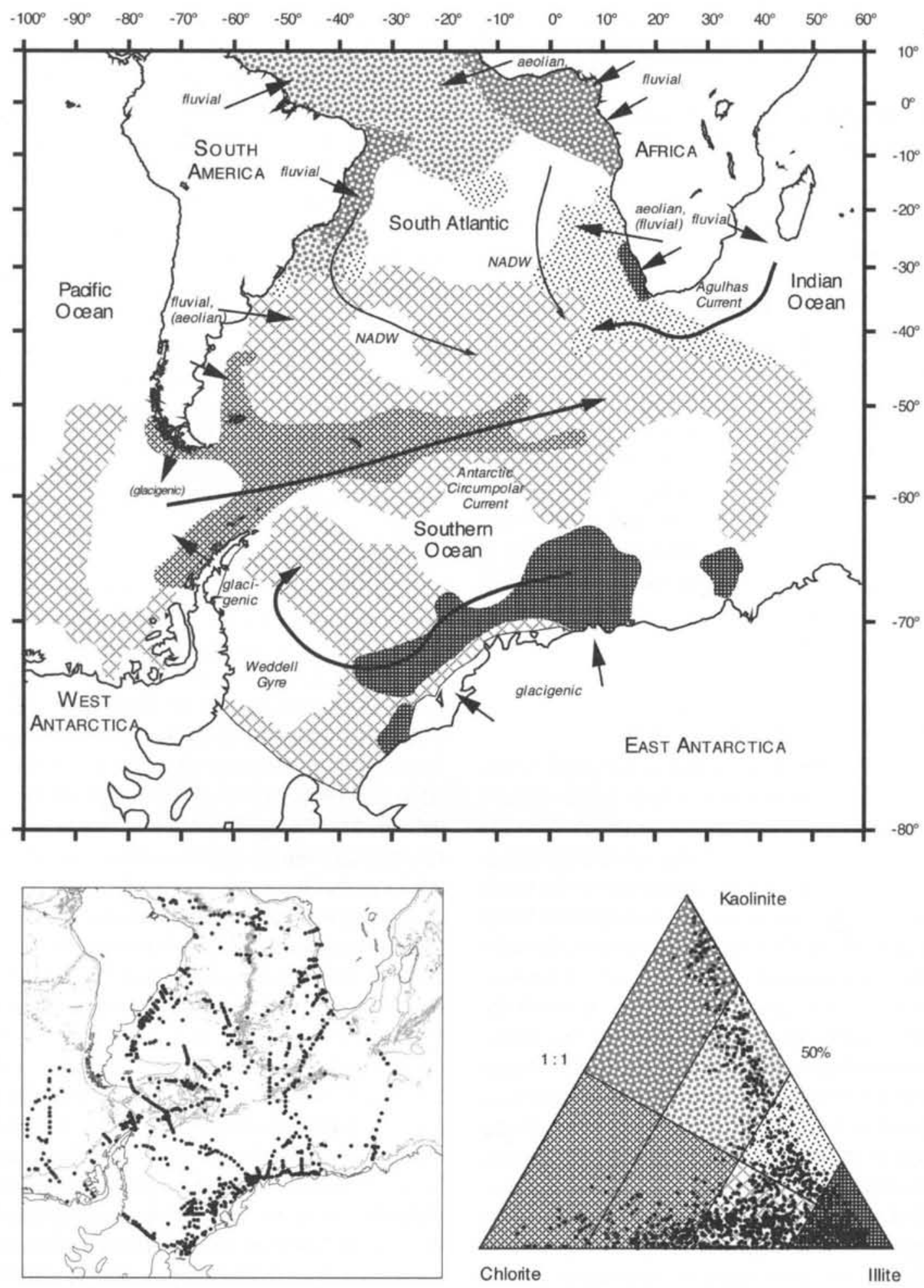

Fig. 6. Modern clay-mineral provinces and modes of terrigenous clay supply and dispersal. Lower left map shows the distribution of sea-bottom samples (black circles) and illustrates the data base (Petschick et al. 1996; Diekmann et al. 2000). The ternary concentration diagram visualizes the definition of clay-mineral asssemblages, according to the proportions of the three terrigenous clay-mineral groups kaolinite, chlorite, and illite. 
province fringes East Antarctica, reflecting the widespread presence of crystalline basement rocks (Petschick et al. 1996). In contrast, southern Weddell Sea sediments include mixed clay-mineral assemblages (Ehrmann et al. 1992; Melles et al. 1994).

\section{Temporal Variability of Clay-Mineral Assemblages}

Along the Antarctic continental margin, the downcore clay-mineral distributions show distinct glacialinterglacial variations off East Antarctica and the Antarctic Peninsula. A common leit-motif is the alternation of local clay-mineral input during glacial times versus lateral clay-mineral supply from more distant sources during interglacial stages, as indicated by typical key minerals that differ regionally (Fig. 7). The local signal can be attributed to the glacigenic sediment supply by advanced and grounded ice sheets on the shelves that dilute the lateral hemipelagic signal produced by deep and shallow coastal currents (Grobe and Mackensen 1992; Diekmann and Kuhn 1997; Diekmann et al. 2000; Hillenbrand and Ehrmann 2001). Thus, location PS1821 at the Gunnerus Ridge during interglacials is bathed by water masses that carry kaolinite from the Indian sector to the west, while during cold stages it receives more illite from crystalline basement rocks of the hinterland. Off Kapp Norvegia (PS1648), a higher supply of corrensite (mixed-layered smectite-chlorite clay mineral) from local magmatic sources admixes with illite-bearing water masses during glacial stages. In the Bellingshausen Sea (PS1565), chlorite from the central Antarctic Peninsula dilutes the hemipelagic smectite signal during glacial stages. Also in the northern Scotia Sea (PS2515), continental ice dynamics manifested itself as temporal clay-mineral fluctuations (Fig. 7). There, low smectite/chlorite ratios together with elevated MARTs indicate a strong chlorite supply from southern South America in response to extended Patagonian ice fields.

In the northern part of the study area, downcore clay-mineral fluctuations are of lower amplitude than farther south, pointing to relatively constant sediment sources through time (Diekmann et al.
1996). Downcore variations merely concern the proportions of kaolinite and chlorite that originate from distant and opposite sources. Sediment cores from that area (GeoB2110, PS2498, PS2821/Site 1089) show common downcore fluctuations in their kaolinite/chlorite ratios (Fig. 7). These glacialinterglacial contrasts are shown by maps of kaolinite/chlorite ratios in modern sea-bottom sediments and sediments of the last glacial maximum (Fig. 8). Both time slices exhibit pronounced latitudinal gradients of kaolinite/ chlorite ratios, which underline the low-latitude character of kaolinite and the high-latitude character of chlorite. Compared to the modern situation, the map of kaolinite/chlorite ratios of the last glacial maximum reveals a general shift of low kaolinite/chlorite ratios towards lower latitudes. The clay minerals kaolinite and chlorite reflect the modes of sediment supply through time and are good tracers of water-mass advection, as revealed by the present distribution of clay-mineral provinces.

Along the Brazilian continental margin (GeoB 2110) (Fig. 7), temporal variations in kaolinite/ chlorite ratios mainly monitor changes in glacialinterglacial changes in river runoff and the discharge of kaolinite-bearing sediment plumes to mid-water depths in response to alternating humid and arid climate conditions in the Brazilian hinterland (Gingele et al. 1999). Accordingly, fluvial detrital input is reduced during arid glacial periods, causing a decline in kaolinite supply. Another effect in glacial periods that reduces kaolinite/chlorite ratios is the farther northward and increased vertical extension of chlorite-bearing southern-source deep and bottom water masses, which enhance chlorite advection in the area (Jones 1984; Massé et al. 1996; Diekmann et al. 1999) and is also indicated by higher concentrations of displaced Antarctic diatoms in sediments related to glacial periods (Jones and Johnson 1984). On the time-slice maps, these modified processes are indicated by lower values and less pronounced vertical gradients of kaolinite/ chlorite ratios in the Vema Channel region for the last glacial situation (Fig. 8).

Temporal variations of kaolinite/chlorite ratios on the Mid-Atlantic Ridge (PS2498) can be attributed to alternating modes in water-mass advection, 


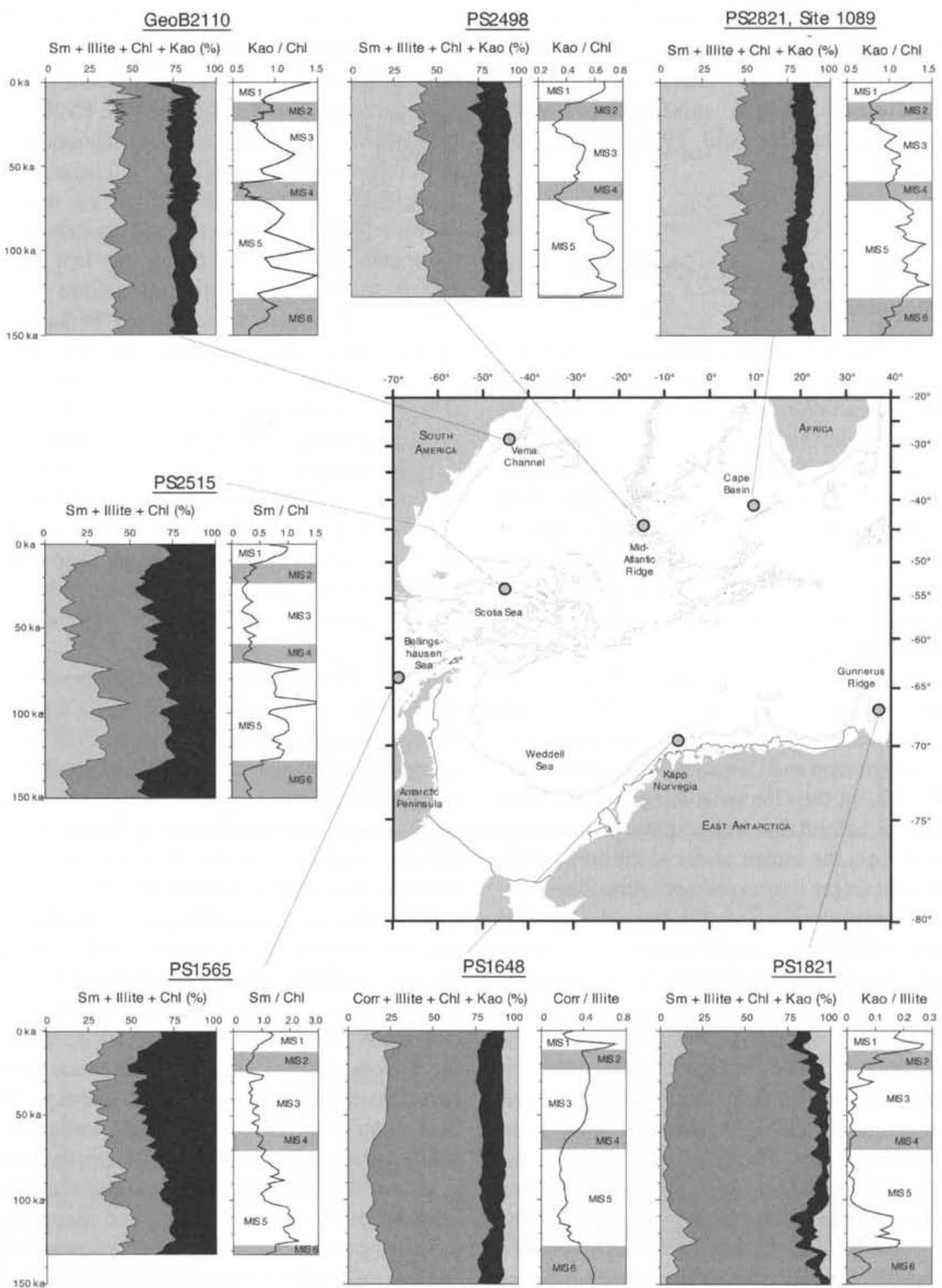

Fig. 7. Temporal (last $150 \mathrm{kyr}$ ) and spatial variability of clay-mineral assemblages in sediment cores of the study area, $(\mathrm{Sm})$ smectite, (Kao) kaolinite, (Chl) chlorite, (Corr) corrensite. Diagrams for each sediment core display clay-mineral percentages (left diagram) and clay-mineral ratios (right diagram) with indication of marine isotope stages (glacial stages in grey). Bathymetry on the map is shown by the 3000 -m contour line. 

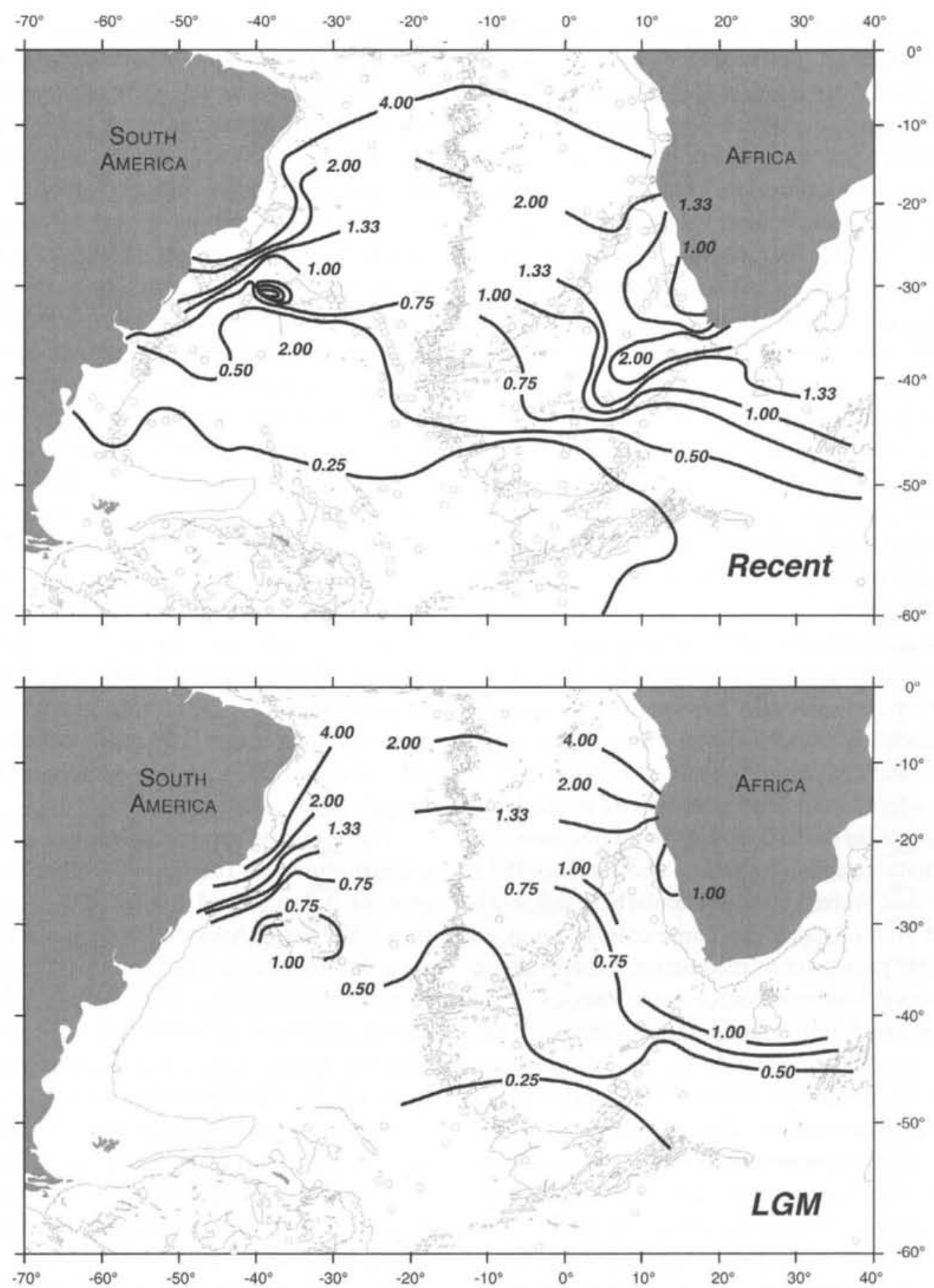

Fig. 8. Time-slice reconstructions of kaolinite/chlorite ratios in modern sea-bottom sediments (Recent, upper map) and marine sediments of the last glacial maximum (LGM, lower map), documenting particle advection in different water masses. Compared to the Recent situation the LGM map shows a displacement of low kaolinite/chlorite ratios to the northeast towards lower latitudes and to shallower water depths on topographic highs, because of a wider extension of chlorite-bearing southern-source water masses and a reduced influx of kaolinite-bearing North Atlantic Deep Water. Moreover, the Recent tongue of high kaolinite/chlorite ratios off southern Africa disappears on the LGM map, which can be explained by a reduced leakage of the kaolinite-bearing Agulhas Current into the South Atlantic. Open circles indicate locations of sediment cores used for reconstruction. 
with a wide propagation of chlorite-bearing water masses of the ACC and a reduced influx of kaolinitebearing NADW into the ACC during glacial periods (Diekmann et al. 1999). This interpretation is supported by the contour-line pattern of kaolinite/ chlorite ratios, which exhibit a marked northeastward bulge of low values beyond the MidAtlantic Ridge for the last glacial situation (Fig. 8). Beside modified water-mass configurations, the changes in clay-mineral ratios can also be attributed to variable clay-mineral fluxes in the opposite water masses. As pointed out, ACC water masses are fed by glacigenic chlorite during glacial periods, whereas NADW receives abundant kaolinite during interglacials, when kaolinite-bearing NADW passes the Vema Channel region and migrates towards the Mid-Atlantic Ridge. These contrasts may overprint the water-mass-related clay-mineral signal to a certain degree.

The reconstruction of the operational modes of South Atlantic ocean circulation (Figs. 1,2) in response to cyclic climate changes is of worldwide significance, because the water masses in the South Atlantic present part of the global conveyor circulation, which apart from atmospheric processes is responsible for the interhemispheric teleconnection of climate signals (Broecker and Denton 1989, Berger and Wefer 1996). Particularly in the southeastern South Atlantic, kaolinite/chlorite ratios are a suitable parameter to reconstruct particle advection within southern-source water masses of the ACC, within North Atlantic Deep Water (NADW) that is injected into the ACC, and within water masses of the Agulhas Current that enter the South Atlantic. High kaolinite/chlorite ratios in interglacial intervals document the inflow of kaolinite-bearing suspensions, entrained in the filaments of the Agulhas-Current retroflection and within NADW. Glacial periods are represented by low kaolinite/ chlorite ratios, when the region is mainly bathed by ACC water masses. In the time-slice maps of kaolinite/chlorite ratios, the influence of the Agulhas Current on detrital fluxes is displayed by a contourline tongue of high kaolinite/chlorite ratios for the Recent situation that extends from the Indian Ocean into the South Atlantic (Fig. 8). For the LGM situation, kaolinite/chlorite ratios are lower.
The palaeoclimatic relevance of the temporal variability in regional ocean circulation is underlined by time-series analyses of the clay-mineral parameters (Diekmann et al. 1996; Kuhn and Diekmann 2002a). The results reveal significant spectral power in the $100-\mathrm{kyr}^{-1}, 41-\mathrm{kyr}^{-1}$, and 23$\mathrm{kyr}^{-1}$ frequency bands of orbital eccentricity, obliquity, and precession. Moreover, the inferred palaeoceano-graphic variability is coherent and in phase with changes in (northern-hemispheric) ice volume and NADW production. Apart from Milankovitch cycles, variations in regional ocean circulation are also evident on a millennial time scale, particularly for MIS 3 (Kuhn and Diekmann 2002a). Thus, for interglacial periods, the operation of the modern warm-route conveyor mode is evident, implying a far southward injection of relatively warm and saline NADW into the ACC, compensated to a large extent by the northward outflow of warm surface and intermediate waters, which enter the South Atlantic via the Agulhas Current (Gordon et al. 1992). During glacial stages, the conveyor operates in cold route, which is characterized by prevailing cold southern-source water masses in the study area.

These results support palaeoceanographic reconstructions on the basis of other water-mass proxies. A diminished leakage of the Agulhas Current to the South Atlantic during glacial periods is recorded by changes in nannofossil assemblages in marine sediments off the South African cape region (Flores et al. 1999) and by strontium isotopes in detrital material in marine sediments of the southern Cape Basin (Goldstein et al. 1999). Benthic foraminiferal assemblages (Schmiedl and Mackensen 1997) and benthic foraminiferal $\delta^{13} \mathrm{C}$ variations in South Atlantic sediment cores (Duplessy et al. 1988; Charles and Fairbanks 1992; Mackensen and Bickert 1999) both suggest a weakened NADW influx to the south during glacial periods. Moreover, benthic foraminiferal $\delta^{13} \mathrm{C}$ records document a variable $\mathrm{NADW}$ influx on a millennial time scale, but on higher frequency as suggested by the clay-mineral proxy (Charles et al. 1996).

From these findings, it can be stated that regional ocean circulation in the South Atlantic is 
connected with global conveyor circulation and northern-hemispheric climate processes. Other palaeoceanographic changes in the ACC region seem to be dictated by southern-hemispheric processes, as suggested, for example, by variations in sea-surface temperatures that generally lead changes in conveyor circulation (Charles et al. 1996; Brathauer and Abelmann 1999). The coupling of northern-hemispheric processes with the South Atlantic is also evident on a longer time scale, as deduced from the Quaternary oxygen-isotope and clay-mineral record of Site 1090, which was also drilled during Leg 177 of the Ocean Drilling Program in the southeastern South Atlantic (Diekmann and Kuhn 2002) (Fig. 9). Thus the onset of the modern glacial-interglacial pattern in regional circulation at $1200 \mathrm{ka}$ and the development of strong glacial-interglacial contrasts after the mid-Pleistocene around $650 \mathrm{ka}$ match a corresponding temporal pattern in NADW production in the North Atlantic and the adjoining northern seas (Henrich and Baumann 1994; Henrich et al. 2002).
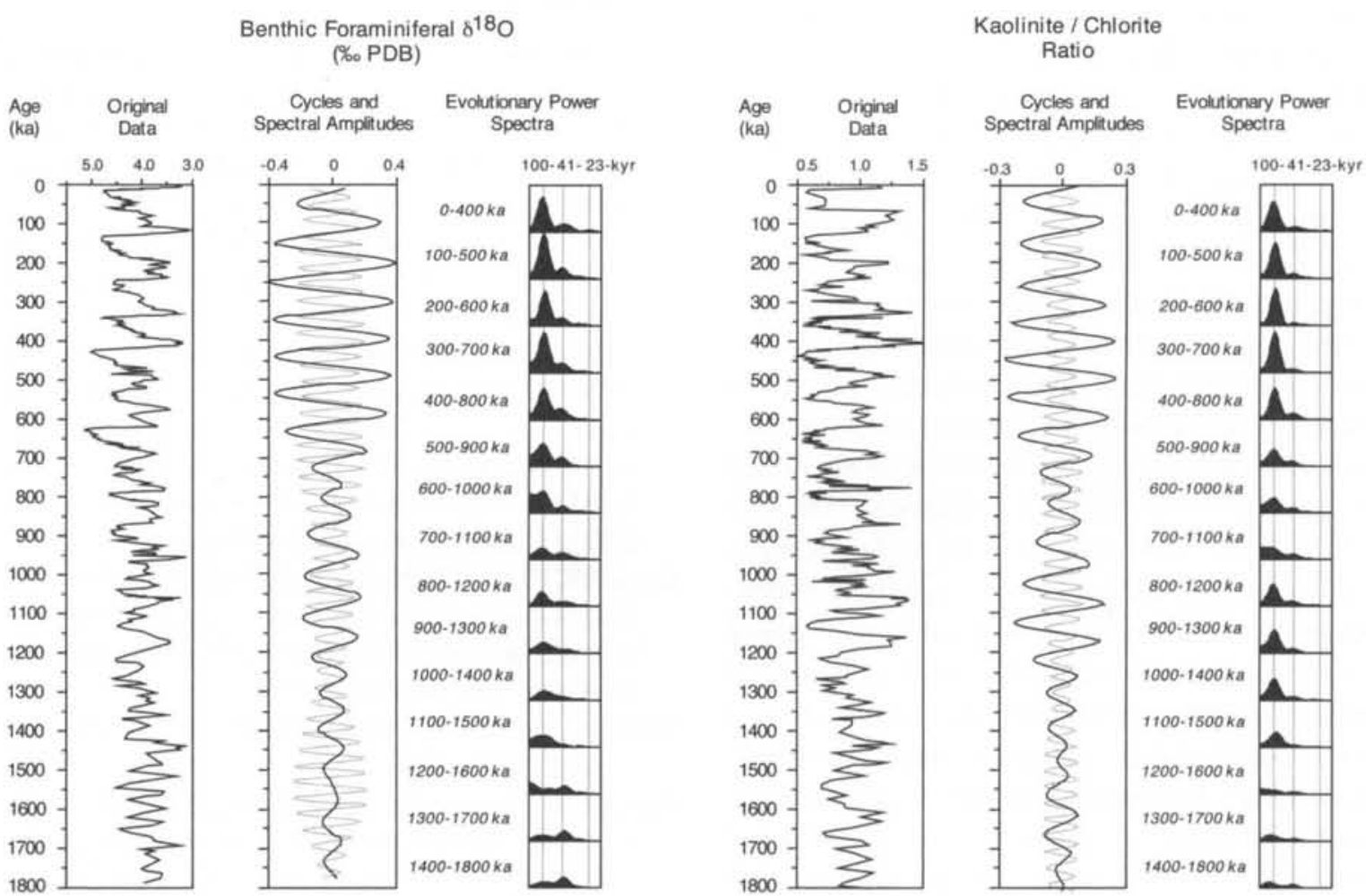

Fig. 9. Temporal fluctuations of benthic foraminiferal $\delta^{18} \mathrm{O}$ ratios (Becquey and Gersonde 2002) and kaolinite/ chlorite ratios (Diekmann and Kuhn 2002) at ODP Site 1090 in the southeastern South Atlantic. Cyclicity and spectral amplitudes of 100-kyr and 41-kyr periods were deduced from Gaussian filtering. Evolutionary power spectra are based on Blackman-Tuckey time-series analyses on 400-kyr intervals at steps of $100 \mathrm{kyr}$. Note the development of 100-kyr cycles across the mid-Pleistocene climate transition between $1200 \mathrm{ka}$ and $650 \mathrm{ka}$ and their marked strengthening after $600 \mathrm{ka}$, displayed by both parameters. These common spectral features underline the close relationship between global ice volume (oxygen isotope parameter) and ocean circulation in the southeastern South Atlantic (kaolinite/chlorite ratios). Modified from Diekmann and Kuhn (2002). 


\section{Conclusions}

Detrital sources and modes of terrigenous sediment supply in the polar to temperate South Atlantic reflect glacial-interglacial environmental changes in response to late Quaternary climate cycles.

Mass-accumulation rates of terrigenous sediment depend on the detrital influx driven by advancing ice masses, fluvial discharge and aeolian influx and reflect the intensity of bottom-current transport. The spatial and temporal pattern of icerafted detritus (IRD) in marine sediments along Antarctica and in the Scotia Sea reflects the calving rates of Antarctic and Patagonian ice masses, while IRD abundances in the southeastern South Atlantic are related to the presence of cold surface waters. High proportions of coarse silt in the mud fraction of terrigenous sediments point to increased bottomcurrent strengths. Clay minerals indicate the sources of terrigenous mud and trace the dispersal of fine-grained suspensions by water-mass advection within ocean currents.

The combined interpretation of the various terrigenous sediment parameters suggests East Antarctic ice dynamics with dominant 100-kyr cycles and high rates of Antarctic Bottom Water formation and iceberg discharge during interglacial times with floating ice shelves because of high sea level. The more subpolar ice masses of the Antarctic Peninsula and Patagonia respond with maximum iceberg discharges during glacial terminations related to the rapid disintegration of advanced ice masses. In the northern Scotia Sea, increased sediment supply from southern South America points to extended ice masses in Patagonia during glacial times. In the southeastern South Atlantic, changes in regional ocean circulation are linked to global conveyor circulation and are in phase with northern-hemispheric processes of ice build-up and the associated formation of North Atlantic Deep Water, which decreases during glacial times and permits a wider extension of southern-source water masses in the study area.

\section{Acknowledgements}

This study was funded by the Deutsche Forschungsgemeinschaft through the Sonderfor- schungsbereich 261 at Bremen University and at the Alfred Wegener Institute in Bremerhaven and through grant Di-655/2. We appreciate the kind assistance of ship crews and scientists. For sample preparation and technical support during the last years, we are indebted to Rita Froehlking, Silvia Janisch, Norbert Lensch, Walter Luttmer, Helga Rhodes ( $\dagger$ ), Michael Seebeck, Maren Thomas, Franziska Stenzel, Jutta Vernaleken, and numerous student trainees. Finally we acknowledge the reviews of Carol Pudsey, Steven Hovan and an anonymous referee. This is SFB-261 contribution No. 363 and AWI publication No. 10492. Data are available under www.pangaea.de/Projects/SFB261.

\section{References}

Allen CP, Warnke DA (1991) History of ice-rafting at Leg 114 sites, Subantarctic/South Atlantic. Proceedings ODP, Scientific Results 114: 599-607 Anderson JB (1999) Antarctic Marine Geology. Cambridge University Press, Cambridge, $289 \mathrm{p}$

Anderson JB, Kurtz D (1985) The use of silt grain size parameters as a paleovelocity gauge: A critical review and case study. Geo-Mar Lett 5: 55-59

Anderson JB, Andrews BA, Bartek LR, Truswell EM (1989) Petrology and palynology of Weddell Sea glacial sediments: Implications for subglacial geology. In: Thomson MRA, Crame JA, Thomson JW (eds) Geological Evolution of Antarctica. Cambridge University Press, Cambridge, pp 231-235

Aston SR, Chester R, Johnson LR, Padgham RC (1973) Eolian dust from the lower atmosphere of the eastern Atlantic, and Indian Ocean, China Sea and Sea of Japan. Mar Geol 14: 15-28

Bard E (1999) Ice age temperatures and geochemistry. Science 284: 1133-1134

Bareille G, Grousset FE, Labracherie M, Labeyrie LD, Petit JR (1994) Origin of detrital fluxes in the southeast Indian Ocean during the last climatic cycles. Paleoceanography 9: 799-819

Barrett PJ (1996) Antarctic palaeoenvironment through Cenozoic times - a review. Terra Antartica 3: 103-119

Becquey S, Gersonde R (2002) Past hydrographic and climatic changes in the Subantarctic Zone of the South Atlantic - The Pleistocene record from ODP Site 1090. Palaeogeogr Palaeoclimatol Palaeoecol 182: 221-239

Berger WH, Wefer G (1996) Expeditions into the past: paleoceanographic studies in the South Atlantic. In: Wefer G, Berger WH, Siedler G, Webb DJ (eds) The 
South Atlantic: Present and Past Circulation. Springer, Berlin, pp 363-410

Bickert T, Wefer G (1996) Late Quaternary deep water circulation in the South Atlantic: Reconstruction from carbonate dissolution and benthic stable isotopes. In: Wefer G, Berger WH, Siedler G, Webb DJ (eds) The South Atlantic: Present and Past Circulation. Springer, Berlin, pp 599-620

Biscaye PE (1964) Distinction between kaolinite and chlorite in Recent sediments by x-ray diffraction. Am Mineral 49: 1281-1289

Biscaye PE (1965) Mineralogy and sedimentation of recent deep-sea clay in the Atlantic Ocean and adjacent seas and oceans. Geol Soc Am Bull 76: 803-832

Biscaye PE, Dasch EJ (1971) The rubidium, strontium, strontium-isotope system in deep-sea sediments: Argentine Basin. J Geophys Res 76: 5087-5096

Biscaye PE, Eittreim SL (1977) Suspended particulate loads and transports in the nepheloid layer of the abyssal Atlantic Ocean. Mar Geol 23: 155-172

Bonn WJ, Gingele FX, Grobe H, Mackensen A, Fütterer DK (1998) Palaeoproductivity at the Antarctic continental margin: opal and barium records for the last 400 ka. Palaeogeogr Palaeoclimatol Palaeoecol 139: 195-211

Bornhold BD, Summerhayes CP (1977) Scour and deposition at the foot of the Walvis Ridge in the northernmost Cape Basin, South Atlantic. Deep-Sea Res 24: 743-752

Brathauer U, Abelmann A (1999) Late Quaternary variations in sea-surface temperatures and their relationship to orbital forcing recorded in the Southern Ocean (Atlantic sector). Paleoceanography 14: 135-148

Brehme I (1992) Sedimentfazies und Bodenwasserstrom am Kontinentalhang des nordwestlichen Weddellmeeres. Ber Polarforsch, Bremerhaven 110,127 p

Bremner JM, Willis JP (1993) Mineralogy and geochem-istry of the clay fraction of sediments from the Namibian continental margin and the adjacent hinterland. Mar Geol 115: 85-116

Broecker W, Denton GH (1989) The role of ocean-atmosphere reorganizations in glacial cycles. Geochim Cosmochim Acta 53: 2465-2501

Chamley H (1989) Clay Sedimentology. Springer, Berlin, $623 \mathrm{p}$

Chamley H (1997) Clay mineral sedimentation in the ocean. In: Paquet H, Clauer N (eds) Soils and Sediments: Mineralogy and Geochemistry. Springer, Berlin, pp 269-302

Charles CD, Fairbanks RG (1992) Evidence from Southern Ocean sediments for the effect of North
Atlantic Deep Water flux on climate. Nature 355: 416-419

Charles CD, Lynch-Stieglitz J, Ninnemann US, Fairbanks RG (1996) Climate connections between the hemispheres revealed by deep-sea sediment core / ice core correlations. Earth Planet Sci Lett 142: 19-27

Cofaigh CO, Dowdeswell JA, Pudsey CJ (2001) Late Quaternary iceberg rafting along the Antarctic Peninsula continental rise and in the Weddell and Scotia Seas. Quat Res 56: 308-321

Conolly JR, Ewing M (1965) Ice-rafted detritus as a climatic indicator in Antarctic deep-sea cores. Science 150: $1822-1824$

Cooke DW, Hays JD (1982) Estimates of Antarctic Ocean seasonal sea-ice cover during glacial intervals. In: Craddock C (ed) Antarctic Geoscience. University of Wisconsin Press, Madison, pp 1017-1027

Cortese G, Abelmann A (2002) Radiolarian-based paleotemperatures during the last $160 \mathrm{kyrs}$ at ODP Site 1089 (Southern Ocean, Atlantic Sector). Palaeogeogr Palaeoclimatol Palaeoecol 182: 259-286

De Melo U, Summerhayes CP, Ellis JP (1975) Salvador to Vitoria, southeastern Brazil, part IV. In: Milliman JD, Summerhayes CP (eds) Upper Continental Margin Sedimentation off Brazil. Contributions to Sedimentology, Vol 4, Schweizerbart, Stuttgart, pp 78-116

Diekmann B, Kuhn G (1997) Terrigene Partikeltransporte als Abbild spätquartärer Tiefen- und Bodenwasserzirkulation im Südatlantik und angrenzendem Südpolarmeer. Z Deut Geol Ges 148: 405-429

Diekmann B, Kuhn G (1999) Provenance and dispersal of glacial-marine surface sediments in the Weddell Sea and adjoining areas, Antarctica: Ice-rafting versus current transport. Mar Geol 158: 209-231

Diekmann B, Kuhn G (2002) Sedimentary record of the mid-Pleistocene climate transition in the sub-Antarctic South Atlantic (ODP Site 1090). Palaeogeogr Palaeoclimatol Palaeoecol 182: 241-258

Diekmann B, Petschick R, Gingele FX, Fütterer DK, Abelmann A, Brathauer U, Gersonde R, Mackensen A (1996) Clay mineral fluctuations in late Quaternary sediments of the southeastern South Atlantic: Implications for past changes of deep water advection. In: Wefer G, Berger WH, Siedler G, Webb DJ (eds) The South Atlantic: Present and Past Circulation. Springer, Berlin, pp 621-644

Diekmann B, Kuhn G, Mackensen A, Petschick R, Fütterer DK, Gersonde R, Rühlemann C, Niebler HS (1999) Kaolinite and chlorite as tracers of modern and late Quaternary deep water circulation in the South Atlantic and the adjoining Southern Ocean. In: Fischer G, Wefer G (eds) Use of Proxies in 
Paleoceanography: Examples from the South Atlantic. Springer, Berlin, pp 285-313

Diekmann B, Kuhn G, Rachold V, Abelmann A, Brathauer U, Fütterer DK, Gersonde G, Grobe H (2000) Ter-rigenous sediment supply in the Scotia Sea (Southern Ocean): Response to Late Quaternary ice dynamics in Patagonia and on the Antarctic Peninsula. Palaeogeogr Palaeoclimatol Palaeoecol 162: $357-387$

Dittert N, Baumann K-H, Bickert T, Henrich R, Huber R, Kinkel H, Meggers H (1999) Carbonate dissolution in the deep-sea: Methods, quantification and pale-oceanographic application. In: Fischer G, Wefer G (eds) Use of Proxies in Paleoceanography: Examples from the South Atlantic. Springer, Berlin, pp 255-284

Duce RA, Liss PS, Merrill JT, Atlas EL, Buat-Menard P, Hicks BB, Miller JM, Prospero JM, Arimoto R, Church TM, Ellis W, Galloway JN, Hansen L, Jickells TD, Knap AH, Reinhardt KH, Schneider B, Soudine A, Tokos JJ, Tsunogai S, Wollast R, Zhou M (1991) The atmospheric input of trace species to the world ocean. Glob Biogeochem Cycl 5: 193-259

Duplessy JC, Shackleton NJ, Fairbanks RG, Labeyrie LD, Oppo D, Kallel N (1988) Deep water source variations during the last climatic cycle and their impact on global deep water circulation. Paleoceanography $3: 343-360$

Edwards DS, Goodell HG (1969) The detrital mineralogy of ocean floor surface sediments adjacent to the Antarctic Peninsula. Mar Geol 7: 207-234

Ehrmann WU (1994) Die känozoische Vereisungsgeschichte der Antarktis. Ber Polarforsch, Bremerhaven $137,152 \mathrm{p}$

Ehrmann WU, Melles M, Kuhn G, Grobe H(1992) Significance of clay mineral assemblages in the Antarctic Ocean. Mar Geol 107: 249-273

Fahrbach E, Beckmann A (2001) Weddell Sea Circulation. In: Steele JH, Turekian KK, Thorpe SA (eds) Encyclopedia of Ocean Sciences. Academic Press, San Diego, pp 560-570

Flores JA, Gersonde R, Sierro FJ (1999) Pleistocene fluctuations in the Agulhas Current Retroflection based on the calcareous plankton record. Mar Micro-paleontol 37: 1-22

Foldvik A, Gammelsrød T (1988) Notes on Southern Ocean hydrography, sea-ice and bottom water formation. Palaeogeogr Palaeoclimatol Palaeoecol 67: 3-17

Frank M, Gersonde R, Rutgers van der Loeff M, Kuhn G, Mangini A (1996) Late Quaternary sediment dating and quantification of lateral sediment redistribution applying 230-Th-ex: A study from the eastern Atlantic sector of the Southern Ocean. Geol Rundsch 85: 554-566

Fütterer DK, Grobe H, Grünig S (1988) Quaternary sediment patterns in the Weddell Sea: Relations and environmental conditions. Paleoceanography 3 : 551-361

Georgi DT (1981) Circulation of bottom waters in the southwestern South Atlantic. Deep-Sea Res 28: 959 979

Gersonde R, Hodell DA, Blum P et al. (1999) Proceedings ODP, Initial Reports, 177 [CD-ROM]. Available from: Ocean Drilling Program, Texas A\&M University, College Station, TX 77845-9547, USA

Gersonde R, Abelmann A, Brathauer U, Becquey S, Bianchi C, Cortese G, Grobe H, Kuhn G, Niebler H-S, Segl M, Sieger R, Zielinski U, Fütterer DK (2003) Last glacial sea-surface temperatures and sea-ice extent in the Southern Ocean (Altanic-Indian sector) - A multiproxy approach. Paleoceanography 18: 1061, doi 10.1029/2002PA000809

Gilbert IM, Pudsey CJ, Murray JW (1998) A sediment record of cyclic bottom-current variability from the northwest Weddell Sea. Sediment Geol 115: 185214

Gingele FX (1996) Holocene climatic optimum in Southwest Africa - evidence from the marine clay mineral record. Palaeogeogr Palaeoclimatol Palaeoecol 122: 77-87

Gingele FX, Müller PM, Schneider RR (1998) Orbital forcing of freshwater input in the Zaire Fan area clay mineral evidence from the last $200 \mathrm{kyr}$. Palaeogeogr Palaeoclimatol Palaeoecol 138: 17-26

Gingele FX, Schmieder F, von Dobeneck T, Petschick $\mathrm{R}$, Rühlemann C (1999) Terrigenous flux in the Rio Grande Rise area during the past $1500 \mathrm{ka}$ : Evidence of deepwater advection or rapid response to continental rainfall patterns? Paleoceanography 14 : 84-95

Goldstein SL, Hemming SR, Kish S, Rutberg R (1999) Strontium isotopes in South Atlantic detritus: A surface current proxy and tracer of Agulhas leakage. Ninth Annual Goldschmidt Conference. Lunar Planet Inst, Houston, TX pp \#7537 [CD-ROM]

Gordon AL, Weiss RF, Smethie WMJ, Warner MJ (1992) Thermocline and intermediate water communication between the South Atlantic and Indian Oceans. J Geophys Res 97: 7223-7240

Grobe H (1987) A simple method for the determination of ice-rafted debris in sediment cores. Polarforschung 57 : 123-126 
Grobe H, Mackensen A(1992) Late Quaternary climate cycles as recorded in sediments from the Antarctic continental margin. In: Kennett JP, Warnke DA(eds) The Antarctic Paleoenvironment: A Perspective on Global Change, Part One. Antarctic Research Series, Vol. 56, American Geophysical Union, Washington DC, pp 349-376

Grousset FE, Biscaye PE, Revel M, Petit JR, Pye K, Joussaume S, Jouzel J (1992) Antarctic (Dome C) ice core dust at $18 \mathrm{ky} \mathrm{BP}$ : Isotopic constraints on origins. Earth Planet Sci Lett 111: 175-182

Henrich R, Baumann KH (1994) Evolution of the Norwegian Current and the Scandinavian Ice Sheets during the past 2.6 my: Evidence from ODP Leg 104 biogenic carbonate and terrigenous records. Palaeogeogr Palaeoclimatol Palaeoecol 108: 75-94

Henrich R, Baumann KH, Huber R, Meggers H (2002) Carbonate preservation records of the past $3 \mathrm{Myr}$ in the Norwegian-Greenland Sea and the northern North Atlantic: Implications for the history of NADW production. Mar Geol 184: 17-39

Heusser CJ, Heusser LE, Lowell TV, Moreira AM, Moreira SM (2000) Deglacial palaeoclimate at Puerto del Hambre, subantarctic Patagonia, Chile. J Quater Sci 15: 101-114

Hillenbrand CD (1994) Spätquartäre Sedimentationsprozesse am Kontinentalrand des nordöstlichen Bellingshausenmeeres (Antarktis). Diploma Thesis, Universität Würzbug, $124 \mathrm{p}$

Hillenbrand CD (2000) Glazialmarine Sedimentationsentwicklung am westantarktischen Kontinentalrand im Amundsen- und Bellingshausenmeer - Hinweise auf Paläoumweltveränderungen während der quartären Klimazyklen. Ber Polarforsch, Bremerhaven $346,182 \mathrm{p}$

Hillenbrand CD, Ehrmann WU (2001) Distribution of clay minerals in drift sediments on the continental rise west of the Antarctic Peninsula, ODP Leg 178, Sites 1095 and 1096. In: Barker PF, Camerlenghi A, Acton GD, Ramsay ATS (eds) Proceedings ODP, Scientific Results 178, pp 1-29

Hillenbrand CD, Grobe H, Diekmann B, Kuhn G, Fütterer DK (2003) Distribution of clay minerals and proxies for productivity in surface sediments of the Bellings-hausen and Amundsen seas (West Antarctica) - Relation to modern environmental conditions. Mar Geol 193: 253-271

Hodell DA, Charles CD, Sierro FJ (2001) Late Pleistocene evolution of the ocean's carbonate system: A detailed record from Ocean Drilling Program (ODP) Site 1089. Earth Planet Sci Lett 192: 109-124
Höppner R, Henrich R (1999) Kornsortierungsprozesse am Argentinischen Kontinentalhang anhand von Siltkorn-Analysen. Zentralblatt für Geologie und Paläontologie Teil 1 1997: 897-905

Hofmann A (1999) Kurzfristige Klimaschwankungen im Scotiameer und Ergebnisse zur Kalbungsgeschichte der Antarktis während der letzten 200000 Jahre. Ber Polarforsch, Bremerhaven 345, $162 \mathrm{p}$

Howe JA, Pudsey CJ (1999) Antarctic Circumpolar Deep Water: A Quaternary paleoflow record from the northern Scotia Sea, South Atlantic Ocean. J Sediment Res 69: 847-861

Husar RB, Prospero JM, Stowe LL (1997) Characterization of tropospheric aerosols over the oceans with the NOAA advanced very high resolution radiometer optical thickness operational product. J Geophys Res D102: 16889-16909

Imbrie J, Hays JD, Martinson DG, McIntyre A, Mix AC, Morley JJ, Pisias NG, Prell WL, Shackleton NJ (1984) The orbital theory of Pleistocene climate: Support from a revised chronology of the marine $\delta^{18} \mathrm{O}$ record. In: Berger A, Imbrie J, Hays J, Kukla G, Saltzman B (eds) Milankovitch and Climate. NATO ASI SERIES, D Reidel, Dordrecht, pp 269-305

Jones GA (1984) Advective transport of clay minerals in the region of the Rio Grande Rise. Mar Geol 58: $187-212$

Jones GA, Johnson DA (1984) Displaced Antarctic diatoms in Vema Channel sediments: Late Pleistocene/ Holocene fluctuations in AABW flow. Mar Geol 58: 165-186

Kanfoush SL, Hodell DA, Charles CD, Guilderson TP, Mortyn PG, Ninnemann US (2000) Millennial-scale instability of the Antarctic ice sheet during the last glaciation. Science 288: 1815-1818

Keir RS (1988) On the late Pleistocene ocean geochemistry and circulation. Paleoceanogr 3: 413-445

Kolla V, Henderson L, Biscaye P (1976) Clay mineralogy and sedimentation in the western Indian Ocean. Deep-Sea Res 23: 949-961

Kuhn G, Diekmann B (2002a) Late Quaternary variability of ocean circulation in the southeastern South Atlantic inferred from the terrigenous sediment record of a drift deposit in the southern Cape Basin (ODP Site 1089). Palaeogeogr Palaeoclimatol Palaeoecol 182: 287-303

Kuhn G, Diekmann B (2002b). Data report: Bulk sediment composition, grain size, clay and silt mineralogy of Pleistocene sediments from ODP Leg 177 Sites 1089 and 1090. In: Gersonde R, Hodell DA, Blum P (eds) Proc. ODP, Sci. Results, 177 [Online] 
Kumar N, Anderson RF, Mortlock RA, Froelich PN, Kubik P, Dittrich-Hannen B, Suter M (1995) Increased biological productivity and export production in the glacial Southern Ocean. Nature 378: 675-680

Labeyrie LD, Pichon JJ, Labracherie M, Ippolito P, Duprat J, Duplessy JC (1986) Melting history of Antarctica during the past 60,000 years. Nature 322: 701-706

Ledbetter MT (1986) A late Pleistocene time-series of bottom-current speed in the Vema Channel. Palaeogeogr Palaeoclimatol Palaeoecol 53: 97-105

Lisitzin AP (1996) Oceanic Sedimentation. American Geophysical Union, Washington DC, $400 \mathrm{p}$

Locarnini RA, Whitworth III, T, Nowlin Jr WD (1993) The importance of the Scotia Sea on the outflow of Weddell Sea Deep Water. J Mar Res 51: 135-153

Lowell TV, Heusser BJ, Anderson BG, Moreno PI, Hauser A, Heusser LE, Schlüchter C, Marchant DR, Denton GH (1995) Interhemispheric correlation of Late Pleistocene glacial events. Science 269: 15411549

Mackensen A, Bickert T (1999) Stable carbon isotopes in benthic foraminfera. In: Fischer G, Wefer G (eds) Use of Proxies in Paleoceanography: Examples from the South Atlantic. Springer, Berlin, pp 229254

Mackensen A, Rudolph M, Kuhn G (2001) Late Pleistocene deep-water circulation in the subantarctic eastern Atlantic. Glob Planet Change 30: 197-229

Maher BA, Dennis PF (2001) Evidence against dustmediated control of glacial-interglacial changes in atmospheric $\mathrm{CO}_{2}$. Nature 411: 176-180

Mahowald N, Kohfeld K, Hansson M, Balkanski Y, Harrison SP, Prentice IC, Schulz M, Rodhe H (1999) Dust sources and deposition during the last glacial maximum and current climate: A comparison of model results with paleodata from ice cores and marine sediments. J Geophys Res D104: 1589515916

Martin JH (1990) Glacial-interglacial $\mathrm{CO}_{2}$ change: The iron hypothesis. Paleoceanography $5: 1-13$

Massé L, Faugères JC, Bernat M, Pujos A, Mézerais ML (1994) A 600,000-year record of Antarctic Bottom Water activity inferred from sediment textures and structures in a sediment core from the southern Brazil Basin. Paleoceanography 9: 1017-1026

Massé L, Faugères JC, Pujol C, Pujos A, Labeyrie LD, Bernat M (1996) Sediment flux distribution in the southern Brazil Basin during the late Quaternary: the role of deep-sea currents. Sedimentology 43: 115-132
McCave IN, Manighetti B, Robinson SG (1995) Sortable silt and fine sediment size/composition slicing: Parameters for palaeocurrent speed and palaeoceano-graphy. Paleoceanography 10: 593610

McCulloch RD, Bentley MJ, Purves RS, Hulton NRJ, Sudgen DE, Clapperton CM (2000) Climatic inferences from glacial and paleoecological evidence at the last glacial termination, southern South America. J Quat Sci 15: 409-417

Melles M, Kuhn G, Fütterer DK, Meischner D (1994) Processes of modern sedimentation in the southern Weddell Sea, Antarctica - evidence from surface sediments. Polarforschung 64: 45-74

Michels KH, Kuhn G, Hillenbrand CD, Diekmann B, Fütterer DK, Grobe H, Uenzelmann-Neben G (2002) The southern Weddell Sea: Combined contourite-turbidite sedimentation at the southeastern margin of the Weddell Gyre. In: Stow DAV, Pudsey CJ, Howe JA, Faugères JC, Viana Ar (eds) Deepwater Contourite Systems: Modern Drifts and Ancient Series, Seismic and Sedimentary Characteristics. Geol Soc, London, Mem 22, London, pp 305-323

Niebler HS (1995) Rekonstruktion von Paläo-Umweltparametern anhand von stabilen Isotopen und Faunenvergesellschaftungen planktischer Foraminiferen im Südatlantik. Ber Polarforsch, Bremerhaven $167,198 \mathrm{p}$

Orsi AH, Whitworth III, T, Nowlin Jr, WD (1995) On the meridional extent and fronts of the Antarctic Circum-polar Current. Deep-Sea Res 42: 641-673

Oskierski W (1988) Verteilung und Herkunft glazialmariner Gerölle am Antarktischen Kontinentalrand des östlichern Weddellmeeres. Ber Polarforsch, Brermhaven 47, $166 \mathrm{p}$

Paillard D, Labeyrie L, Yiou P (1996) Macintosh program performs time-series analysis. EOS Transactions AGU 77: 379

Pastouret L, Chamley H, Delibrias G, Duplessy J-C, Thiede J (1978) Late Quaternary climate changes in western tropical Africa deduced from deep-sea sedimentation off the Niger delta. Oceanol Acta 1: 217-232

Peterson RG, Stramma L (1991) Upper-level circulation in the South Atlantic Ocean. Prog Oceanogr 26: 1 73

Petit JR, Mounier L, Jouzel J, Korotkevich YS, Kotlyakov VI, Lorius C (1990) Palaeoclimatological implications of the Vostok core dust record. Nature 343: 56-58

Petschick R, Kuhn G, Gingele FX (1996) Clay mineral 
distribution in surface sediments of the South Atlantic: sources, transport, and relation to oceanography. Mar Geol 130: 203-229

Pirrung M, Hillenbrand CD, Diekmann B, Fütterer DK, Grobe H, Kuhn G (2002) Magnetic susceptibility and ice-rafted debris in surface sediments of the Atlantic sector of the Southern Ocean. Geo-Mar Lett 22: $170-180$

Pudsey CJ (1992) Late Quaternary changes in Antarctic Bottom Water velocity inferred from sediment grain size in the northern Weddell Sea. Mar Geol 107: 933

Pudsey CJ, Camerlenghi A (1998) Glacial-interglacial deposition on a sediment drift on the Pacific margin of the Antarctic Peninsula. Antarctic Science 10: 286-308

Pudsey CJ, Howe JA (1998) Quaternary history of the Antarctic Circumpolar Current: Evidence from the Scotia Sea. Mar Geol 148: 83-112

Rebesco M, Larter RD, Barker PF (1996) Giant sediment drifts on the continental rise west of the Antarctic Peninsula. Geo-Mar Lett 16: 65-75

Ruddiman WF (1997) Tropical Atlantic terrigenous fluxes since 25,000 yrs BP. Mar Geol 136: 189-207

Schmiedl G, Mackensen A (1997) Late Quaternary paleo-productivity and deep water circulation in the eastern South Atlantic Ocean: Evidence from benthic foraminifera. Palaeogeogr Palaeoclimatol Palaeoecol 130: 43-80

Smith DG, Ledbetter MT, Ciesielski PF (1983) Icerafted volcanic ash in the southeast Atlantic sector of the Southern Ocean during the last 100,000 years. Mar Geol 53: 291-312

Tucholke BE, Embley RW (1984) Cenozoic regional erosion of the abyssal sea floor off South Africa. In:
Schlee JS (eds) Interregional Unconformities and Hydrocarbon Accumulation. AAPG Memoir 36, American Association of Petroleum Geologists, Tulsa, pp 145-164

Van der Gaast SJ, Jansen JHF (1984) Mineralogy, opal and manganese of middle and late Quaternary sediments of the Zaire (Congo) deep-sea fan: Origin and climatic variation. Netherland J Sea Res 17: 313 341

Venz KA, Hodell DA (2002) New evidence for chnages in Plio-Pleistocene deep water circulation from Southern Ocean ODP Leg 177, Site 1090. Palaeogeogr Palaeoclimatol Palaeoecol 182: 197220

Vogt C (1997) Zeitliche und räumliche Verteilung von Mineralvergesellschaftungen in spätquartären Sedimenten des Arktischen Ozeans und ihre Nützlichkeit als Klimaindikatoren während der Glazial/Interglazialwechsel. Ber Polarforsch, Bremerhaven 251, $309 \mathrm{p}$

Walter HJ, Hegner E, Diekmann B, Kuhn G, Rutgers van der Loeff MM (2000) Provenance and transport of terrigenous sediment in the South Atlantic Ocean and their relations to glacial and interglacial cycles: $\mathrm{Nd}$ and $\mathrm{Sr}$ isotope evidence. Geochim Cosmochim Acta 64: 3813-3827

Weber ME, Bonani G, Fütterer DK (1994) Sedimentation processes within channel-ridge systems, southeastern Weddell Sea, Antarctica. Paleoceanography 9: 1027-1048

Wefer G, Berger WH, Bijma J, Fischer G (1999) Clues to ocean history: A brief overview of proxies. In: Fischer G, Wefer G (eds) Use of Proxies in Paleoceanography: Examples from the South Atlantic. Springer, Berlin, pp 1-68 